\title{
RESEARCH
}

Open Access

\section{Mutant Huntingtin affects toll-like receptor 4 intracellular trafficking and cytokine production in mast cells}

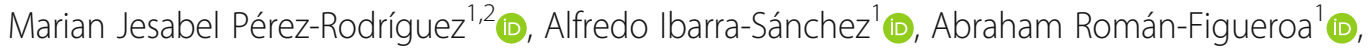 \\ Francisca Pérez-Severiano ${ }^{2}$ (D) and Claudia González-Espinosa ${ }^{1 *}$ (i)
}

\begin{abstract}
Background: Huntington's disease (HD) is caused by the expression of a mutated variant of Huntingtin (mHtt), which results in the complex pathology characterized by a defective function of the nervous system and altered inflammatory responses. While the neuronal effects of mHtt expression have been extensively studied, its effects on the physiology of immune cells have not been fully described. Mast cells (MCs) are unique tissue-resident immune cells whose activation has been linked to protective responses against parasites and bacteria, but also to deleterious inflammatory allergic reactions and, recently, to neurodegenerative diseases.

Methods: Bone marrow-derived mast cells (BMMCs) were obtained from wild-type (WT-) and mHtt-expressing (R6/ 1) mice to evaluate the main activation parameters triggered by the high-affinity IgE receptor (FcERI) and the Tolllike receptor (TLR) 4. Degranulation was assessed by measuring the secretion of $\beta$-hexosaminidase, MAP kinase activation was detected by Western blot, and cytokine production was determined by RT-PCR and ELISA. TLR-4 receptor and Htt vesicular trafficking was analyzed by confocal microscopy. In vivo, MC-deficient mice (c-Kit Wsh Wsh) were intraperitonally reconstituted with WT or R6/1 BMMCs and the TLR4-induced production of the tumor necrosis factor (TNF) was determined by ELISA. A survival curve of mice treated with a sub-lethal dose of bacterial lipopolysaccharide (LPS) was constructed.

Results: R6/1 BMMCs showed normal $\beta$-hexosaminidase release levels in response to FcERl, but lower cytokine production upon LPS stimulus. Impaired TLR4-induced TNF production was associated to the lack of intracellular dynamin-dependent TLR-4 receptor trafficking to perinuclear regions in BMMCs, a diminished ERK1/2 and ELK-1 phosphorylation, and a decrease in c-fos and TNF mRNA accumulation. R6/1 BMMCs also failed to produce TLR4induced anti-inflammatory cytokines (like IL-10 and TGF- $\beta$ ). The detected defects were also observed in vivo, in a MCs-dependent model of endotoxemia. R6/1 and c-Kit Wsh $/$ Wsh mice reconstituted with R6/1 BMMCs showed a decreased TLR4-induced TNF production and lower survival rates to LPS challenge than WT mice.

(Continued on next page)
\end{abstract}

\footnotetext{
* Correspondence: cgonzal@cinvestav.mx

'Departamento de Farmacobiología, Centro de Investigación y de Estudios

Avanzados del IPN, Calzada de los Tenorios 235, Granjas Coapa, Tlalpan,

14330 Mexico City, Mexico

Full list of author information is available at the end of the article
}

(c) The Author(s). 2020 Open Access This article is licensed under a Creative Commons Attribution 4.0 International License, which permits use, sharing, adaptation, distribution and reproduction in any medium or format, as long as you give appropriate credit to the original author(s) and the source, provide a link to the Creative Commons licence, and indicate if changes were made. The images or other third party material in this article are included in the article's Creative Commons licence, unless indicated otherwise in a credit line to the material. If material is not included in the article's Creative Commons licence and your intended use is not permitted by statutory regulation or exceeds the permitted use, you will need to obtain permission directly from the copyright holder. To view a copy of this licence, visit http://creativecommons.org/licenses/by/4.0/ The Creative Commons Public Domain Dedication waiver (http://creativecommons.org/publicdomain/zero/1.0/) applies to the data made available in this article, unless otherwise stated in a credit line to the data. 
(Continued from previous page)

Conclusions: Our data show that $\mathrm{mHtt}$ expression causes an impaired production of pro- and anti-inflammatory

mediators triggered by TLR-4 receptor in MCs in vitro and in vivo, which could contribute to the aberrant

immunophenotype observed in HD.

Keywords: Huntingtin, Mast cells, TLR-4, Signaling, Intracellular receptor trafficking

\section{Background}

Huntington's disease (HD) is a dominant, deleterious neurological condition caused by the synthesis of a mutated variant of the protein Huntingtin (Htt) [1]. Mutant $\mathrm{Htt}(\mathrm{mHtt})$ is characterized by the presence of a $\mathrm{N}$ terminal poly-Q string that causes the protein to misfold, giving new activities to the polypeptide and its aggregates. Since mHtt is expressed in cells from different lineages, HD has been recognized as a complex pathology, clinically defined by brain alterations and changes in immune responses like inflammation [2]. While the effects of mHtt on neurons have been the matter subject of intense research, the effects of $\mathrm{mHtt}$ expression on non-neural cells have not been fully studied.

Mast cells (MCs) are multifunctional innate immune cells, characterized by the presence of numerous electrodense granules in their cytoplasm. In the embryo, MCs are derived from the yolk sac [3], and in adults they are generated in the bone marrow and migrate to vascularized tissues as immature precursors, to complete their differentiation under the influence of locally produced mediators [4]. They are involved in both physiological and pathological immune responses, since upon a proper stimulus they release pre-stored and newly synthesized regulators of inflammation such as histamine, serotonin, proteases, lipid-derived compounds, cytokines, and chemokines. Under physiological conditions, MCs play an important role in tissue homeostasis, host defense, and tissue repair $[5,6]$. They express high levels of the highaffinity IgE receptor (FceRI), which binds the Fc portion of immunoglobulin E. Upon receptor crosslinking when IgE molecules form complexes with specific antigens (IgE/Ag), MCs release the content of their cytoplasmic granules (like the enzyme $\beta$-hexosaminidase) in a reaction known as anaphylactic degranulation. Then, they secrete various cytokines and chemokines that are responsible for the late-phase of allergic reactions [7]. Due to their capacity to produce pro-inflammatory mediators, MCs have been implicated not only in acute immune reactions but also in chronic deleterious conditions, like the neuroinflammation linked to neurodegenerative diseases $[8,9]$.

Studies on murine models have demonstrated that MCs participate in the host defense against invading microbes [10], since they express multiple receptors detecting pathogen-associated molecular patterns (PAMPs) and damage-associated molecular patterns (DAMPS). The Toll-like receptor 4 (TLR-4) is expressed in MCs and is activated by several DAMPs and gram-negative bacteria-derived lipopolysaccharide (LPS) [11]. In vivo, TLR-4 triggering in MCs leads to a rapid and sustained release of the tumor necrosis factor (TNF), which favors mouse survival after the intraperitoneal (i.p.) administration of high LPS doses [5, 12]. After recognizing its ligand, TLR-4 in MCs activates a signaling cascade that triggers the activation of the MAP kinases ERK 1/2, p38, and JNK, as well as the IKB kinase (IKK); this leads to the nuclear translocation of the transcription factors ELK-1 and p65 nuclear factor kappa-light-chain-enhancer of activated B cells $(\mathrm{NFK} \mathrm{B})$, respectively $[13,14]$. Those events initiate a transcriptional program that activates immediate early genes (such as $c$-fos) and genes encoding for pro-inflammatory cytokines (like TNF and interleukin 6, IL-6). Anti-inflammatory cytokines like interleukin 10 (IL-10) and the transforming growth factor $\beta$ (TGF- $\beta$ ) are also produced [15]. On the other hand, IKK and MAPKs phosphorylate key proteins of the cytokine secretion machinery, such as the membrane SNARE protein SNAP23 [12, 16] and the metalloprotease ADAM 17 [17]. Recent evidence indicates that the coupling of TLR-4 to intracellular signaling pathways requires the activity of the GTPase dynamin [18]. In distinct cells, dynamin activity controls endocytosis and intracellular vesicle trafficking because it catalyzes the final step on the budding of clatrhin-coated vesicles from the plasma membrane and other intracellular compartments. Its inhibition by compounds like dynasore not only affects membrane recycling processes but also the activation of intracellular signaling pathways and the synthesis of cytokines in response to physiologic stimuli $[18,19]$. While the activation of both FcERI and TLR-4 in MCs lead to cytokine secretion, the molecular mechanisms involved have been proven to be different, since LPS treatment of MCs fails to trigger anaphylactic degranulation [20]. Despite the current knowledge on the molecular events leading to cytokine production in MCs, several key players in the process remain to be identified.

$\mathrm{Htt}$ is a cytoplasmic protein that has been associated to various essential functions in mammalian cells; the expression levels of $\mathrm{mHtt}$ are known to impact several aspects of cell function. Htt interacts with proteins 
involved in gene expression, intracellular transport, intracellular signaling, and metabolism [21]. For instance, recent evidence suggests that Htt may function as a scaffolding protein in dynamin-dependent endocytosis of membrane receptors and vesicular trafficking [22-24]. Htt participates in the intracellular transport of a variety of organelles, including synaptic precursor vesicles [25], autophagosomes [26], endosomes and lysosomes [27], brain-derived neurotrophic factor (BDNF)-containing vesicles [28], amyloid precursor protein (APP)-positive vesicles [29], and GABA-receptor-containing vesicles [30]. Various murine models have been used to study the role of $\mathrm{Htt}$ in subcellular and physiological responses. In particular, the R6/1 mouse strain is widely utilized because it expresses the exon 1 of the human mHtt gene with approximately 116 CAG repeats. Those mice show a relatively rapid onset and progression of a phenotype that includes weight loss, motor abnormalities, neuropathological sequels, a shortened lifespan, and the presence of $\mathrm{mHtt}$ aggregates in striatal neurons and other cells [31].

The hypothesis that $\mathrm{Htt}$ participates in the processes of signal transduction and cytokine production in MCs is herein tested. To do so, distinctive activation parameters were measured in bone marrow-derived mast cells (BMMCs) from wild-type (WT) mice and the mHttexpressing mouse strain R6/1. The effects of mHtt expression on MC-mediated innate immunity responses were also analyzed in vivo.

\section{Methods}

\section{Mice and genotyping}

mHtt-expressing mice of the strain B6CBA-Tg (HDexon1)61Gpb/1 (R6/1) and the corresponding control (Htt-expressing, WT mice) B6CBAF1/J were purchased from The Jackson Laboratory (Bar Harbor, ME, USA), with stock numbers 002809 and 100011. For experiments in vivo, MC-proficient C57BL/6 J and MCdeficient $c$-Kit ${ }^{W s h / W s h}$ (Wsh) mice were also acquired from The Jackson Laboratory, with stock numbers 000664 and 005051 . When required, animals were kept in a 12-h dark/light cycle in a sterile environment at the Unit for the Production and Use of Laboratory Animals (UPEAL) in the Center for Research and Advanced Studies (Cinvestav). Each animal was genotyped with polymerase chain reaction (PCR) commercial kits, using genomic DNA and following the kit manufacturer's directions.

\section{Reagents and antibodies}

RPMI 1640 medium, monomeric IgE (clone SPE-7), and Escherichia coli (serotype 026:B6) LPS, NP-40, $\beta$ mercaptoethanol (2-ME), phosphate-buffered saline (PBS, Cat. No. P4417), and all reagents required for agarose and polyacrylamide gels were purchased from
Sigma-Aldrich (St. Louis, MO, USA). BMMC complete media components (HEPES, non-essential amino acids, glutamine, penicillin/streptomycin mixture), and fetal bovine serum (FBS) were purchased from Gibco-Life Technologies (Gaithersburg, MD, USA). Murine interleukin 3 (IL-3) and stem cell factor (SCF) were purchased from PeproTech (Rocky Hill, NJ, USA). PVDF was purchased from Perkin Elmer (Boston, MA, USA). FR180204 and BAY117085 were purchased from Tocris Bioscience (Bristol, UK). Antibodies against p-ERK 1/2 (Cat. No. 9101, recognizing pTyr 202/pTyr 204), p-p65 NF-KB (Cat. No. 3033, recognizing pSer 536), and pIKK $\alpha / \beta$ (Cat. No. 2697, recognizing Ser 176/180) were purchased from Cell Signaling Technology (Danvers, MA, USA). Antibodies against p-ELK-1 (Cat. No. ab34270, recognizing $\mathrm{p}$-S383) were purchased from Abcam (Cambridge, UK). Antibodies against TLR-4 receptor used for confocal microscopy were purchased from BioLegend (San Diego, CA, USA) (Cat. No. SA1521, recognizing TLR4/MD2), and those used for flow cytometry (Cat. No. SAB1300056, recognizing Nterminal region of TLR-4 receptor) were purchased from Sigma-Aldrich. Antibodies against $\mathrm{Htt}$ (Cat. No. MAB5374, recognizing glutamine repeats) were purchased from Merck-Millipore (Burlington, MA, USA). Antibodies against FceRI (Cat No. 17-5898-80, against the $\alpha$ subunit) were purchased from eBioscience (Thermo Fisher Scientific, San Diego, CA, USA). Antibodies against $\beta$-actin (Cat. No. SC-81178, recognizing the C-terminus) were purchased from Santa Cruz Biotechnology (Dallas, TX, USA). For Western blot, secondary antibodies (anti-mouse and anti-rabbit) were purchased from Jackson ImmunoResearch (West Grove, PA, USA). PE-conjugated antibodies for flow cytometry were acquired from Amersham Pharmacia Biotech (Little Chalfont, UK). Donkey anti-goat antibody coupled to Alexa Fluor 488, goat anti-rabbit-Alexa Fluor 568, and donkey anti-rat antibody coupled to Alexa Fluor 594 were purchased from Thermo Fisher.

\section{BMMC generation and sensitization with IgE}

Bone marrow samples were obtained from tibias and femurs of WT or R6/1 mice. Bone marrow cells were placed in RPMI 1640 medium supplemented with IL-3 $(20 \mathrm{ng} / \mathrm{mL})$, SCF $(10 \mathrm{ng} / \mathrm{mL}), 10 \% \mathrm{FBS}, 100 \mathrm{IU} / \mathrm{mL}$ of penicillin, $100 \mathrm{mg} / \mathrm{mL}$ of streptomycin, 2-ME $50 \mu \mathrm{M}$, and nonessential amino acids $1 \mathrm{mM}$. The cells were cultured at $37{ }^{\circ} \mathrm{C}$ under a $5 \% \mathrm{CO}_{2}$ atmosphere for $5-$ 7 weeks, replacing the medium every 5-6 days. BMMC differentiation was assessed by detecting FceRI expression on the plasma membrane by flow cytometry; only cultures showing more than $98 \%$ of FceRI-positive cells were used. Before manipulation, the cells were sensitized for $24 \mathrm{~h}$ with $100 \mathrm{ng} / \mathrm{mL}$ of anti-DNP IgE (Clone SPE7). 


\section{Viability test}

The Muse ${ }^{\text {ma }}$ Count Viability Kit (Millipore) was used to determine cell viability. Briefly, $10^{6}$ WT or R6/1 BMMCs were re-suspended for $15 \mathrm{~min}$ in a solution containing the reagent MHC100102 (included in the kit) 1:10 dilution. Dot plots indicating the percentage of live cells in each sample were generated with the Viability Intuitive Software, included in the analyzer.

\section{Flow cytometry}

For each condition, $10^{6} \mathrm{WT}$ or R6/1 BMMCs were incubated with $\operatorname{IgE}(100 \mathrm{ng} / \mathrm{mL})$ for $24 \mathrm{~h}$. Then, the cells were collected and re-suspended in universal blocking reagent (BioGenex, San Ramon, CA) for 5 min at $4{ }^{\circ} \mathrm{C}$. The cells were washed twice with $1 \times$ PBS and incubated with anti-FceRI (1:500 in blocking buffer containing $1 \times$ PBS, $5 \mathrm{~g} / \mathrm{L}$ BSA, $0.5 \mathrm{~g} / \mathrm{L}$ sodium azide), and anti-TLR-4 $\mathrm{N}$-terminal $\mathrm{Ab}$ (1:100 in blocking buffer) for $30 \mathrm{~min}$ at $4{ }^{\circ} \mathrm{C}$. The cells were washed and incubated with a PEcoupled anti-IgG Ab (1:200 in blocking buffer). After $30 \mathrm{~min}$ of incubation at $4{ }^{\circ} \mathrm{C}$, the cells were washed again and re-suspended in 1\% paraformaldehyde (PFA). An anti-isotype staining was performed at the same time. The samples were analyzed in a CytoFLEX LX (BR-V-Y-N-I) flow cytometer (Beckman Coulter, Brea, CA, USA), using the software CytExpert for data acquisition; plots showing $\mathrm{PE}^{+}$populations were generated with the software Kaluza Analysis. An Attune flow cytometer (Beckton Dickinson, Franklin Lakes, NJ, USA) was used in some experiments.

\section{Scanning electron microscopy}

Two million sensitized WT or R6/1 BMMCs were centrifuged to a pellet and washed two times with PBS. The supernatant was discarded and the cells were resuspended in the PBS residue. Then, the cells were let to stand at room temperature for $10 \mathrm{~min}$ in positively charged glass cover slips and fixed with $2.5 \%$ glutaraldehyde for $1 \mathrm{~h}$. After three washes with PBS, the samples were post-fixed with $1 \%$ osmium tetroxide $\left(\mathrm{OsO}_{4}\right)$ for $1 \mathrm{~h}$. The fixed samples were washed three more times with PBS and dehydrated in graded ethanol dilutions: first, $50 \%$ ethanol for $10 \mathrm{~min}$, followed by $60 \%$ ethanol for $10 \mathrm{~min}$, and successively by $70 \%, 80 \%, 90 \%$, and $100 \%$ ethanol for $10 \mathrm{~min}$. Then, the cells were put in the critical drying point, coated by the gold-argon method, and scanned in a JSM-6510LV scanning electron microscope (JEOL, Tokyo, Japan). Images were taken at $25 \mathrm{kV}$ and $7500 \times$ and $5000 \times$ enlargements were obtained.

\section{Transmission electron microscopy}

WT and R6/1 BMMCs were observed by transmission electron microscopy (TEM) following a previously described protocol [32]. Briefly, $2 \times 10^{6}$ sensitized BMMCs were centrifuged to a pellet and fixed in $2.5 \%$ glutaraldehyde, left to stand for $60 \mathrm{~min}$ at room temperature, post-fixed in $1 \% \mathrm{OsO}_{4}$ for $60 \mathrm{~min}$, dehydrated in ethanol, and embedded in Spurr resin (DER 332, Unione Chimica Europea, Milan, Italy). Ultrathin sections (70$\mu \mathrm{m}$ width) were obtained in an ultramicrotome (Ultracut UCT, Leica, Wetzlar, Germany), mounted on etched nickel grids, contrasted with uranyl acetate and lead citrate, and rinsed with distilled water. The grids were analyzed in a JEM-1400 transmission electron microscope (JEOL). Micrographs were taken with a Morada camera (Olympus Soft Imaging Solutions, Muenster, Germany).

\section{RNA extraction and RT-PCR}

Two million IgE-sensitized WT or R6/1 BMMCs were stimulated as required, collected, and lysed using TRIreagent (Sigma-Aldrich) according to the manufacturer's instructions, for total RNA extraction and RT-PCR. cDNA was obtained using the RevertAid First Strand cDNA Synthesis Kit (Thermo Fisher Scientific). The following primers were used: TLR-4, sense 5 '-GCAATG TCTGGCAGGTGTA-3' and antisense 5'-CAAGGG ATAAGAACGCTGAGA-3' [33]; MD-2, sense $5^{\prime}$ ATGTTGCCATTTATTCTCTTTTCGACG-3' and antisense 5' -ATTGACATCACGGCGCTGAATGATG-3' [34]; CD-14, sense 5'-CGTCTAGAAGAACACCAT CGCTGTAAAG-3' and antisense 5'-CGTCTAGAAG AACACCATCGCTGTAAAG-3' [35]; TNF, sense $5^{\prime}$ TTCTGTCTACTGAACTTCGGGGTGATCGGTCC-3' and antisense $5^{\prime}$-GTATGAGATAGCAAATCGGCTG ACGGTGTGGG-3' [36]; GAPDH, sense 5 '-TGAAGG TCGGTGTGAACGGATTTGGC-3' and antisense $5^{\prime}$ CATGTAGGCCATGAGGTCCACCAC-3' [37]; c-fos, sense $5^{\prime}$-CGGGTTTCAACGCCGACTA-3' and antisense 5' -TGGCACTAGAGACGGACAGAT-3' [38]; IL10, sense 5 '-ATGCAGGACTTTAAGGGTTACTTGGG TT-3' and antisense 5'-ATTTCGGAGAGAGGTACA AACGAGGTTT-3'; TGF $\beta$, sense 5'-CGCAACAACG CCATCTATGAGAAA-3' and antisense 5'-TTGCAG GAGCGCACAATCATGTTG-3' [39]. PCR products were resolved on $2 \%$ agarose gels and stained with ethidium bromide. Developed gels were documented in a MiniBIS Pro system (DNR Bio-Imaging Systems, Neve Yamin, Israel) and analyzed with the software Gel Quant Express.

\section{Anaphylactic degranulation assay}

The release of the pre-stored granular mediator ( $\beta$-hexosaminidase) was used as a degranulation indicator in BMMCs. Two-million IgE-sensitized WT or R6/1 cells were placed in $1 \mathrm{~mL}$ of Tyrode's/BSA buffer $(20 \mathrm{mM}$ HEPES pH 7.4, $135 \mathrm{mM} \mathrm{NaCl}, 5 \mathrm{mM} \mathrm{KCl}, 1.8 \mathrm{mM}$ $\mathrm{CaCl}_{2}, 1 \mathrm{mM} \mathrm{MgCl} 2,5.6 \mathrm{mM}$ glucose, and $0.05 \% \mathrm{BSA}$ ) at $37^{\circ} \mathrm{C}$ and added with 2,4-dinitrophenol conjugated to 
human serum albumin (DNP-HSA). After stimulation, the cells were centrifuged at $4{ }^{\circ} \mathrm{C}$ and the supernatants were incubated in citrate buffer with p-nitrophenyl- $N$-acetyl- $\beta$ D-glucosaminide for $60 \mathrm{~min}$ at $37{ }^{\circ} \mathrm{C}$. The reaction was quenched in carbonate buffer and the optical density (OD) was determined at $405 \mathrm{~nm}$. Specific release was calculated as the percentage of total $\beta$-hexosaminidase content in a $0.5 \%$ Triton X-100 cell lysate after subtracting baseline degranulation in non-stimulated cells [40].

\section{Determination of cytokine secretion by ELISA}

Two million WT or R6/1 IgE-sensitized BMMCs were stimulated as described above and centrifuged. The concentration of secreted TNF was measured in about $200 \mu \mathrm{L}$ of supernatant with a cytokine-specific ELISA kit (PeproTech, Cat. No. 900-K54), following the manufacturer's instructions. A standard curve was included in each determination [41].

\section{Western blot}

Two million WT or R6/1 IgE-sensitized BMMCs were re-suspended in $1 \mathrm{~mL}$ of supplemented RPMI and stimulated as required at $37{ }^{\circ} \mathrm{C}$. Then, the cells were centrifuged and lysed in $100 \mu \mathrm{L}$ of $2 \times$ Laemmli buffer supplemented with $4 \mathrm{mM}$ sodium ortho-vanadate and $0.28 \mathrm{M}$ 2-ME. Protein aliquots were resolved by SDSPAGE and transferred to polyvinylidene difluoride (PVDF) membranes. The membranes were blocked with $4 \%$ skimmed milk and incubated overnight with the primary antibodies $(1: 10,000)$ in TBS-T buffer $(25 \mathrm{mM}$ Tris, $0.9 \% \mathrm{NaCl}, 0.05 \%$ Tween-20). The primary antibodies were removed and the membranes were washed three times with TBS-T before incubation with the respective secondary antibody $(1: 15,000$ or $1: 20,000)$. The membranes were washed three times with TBS-T, and protein bands were detected with the chemiluminescent HRP substrate (Millipore). A densitometric analysis was performed with the software Molecular Imager Universal Hood II (Software Image Lab v.5.0, Bio-Rad, Hercules, CA, USA).

\section{Immunofluorescence and confocal microscopy}

After pre-treatment and stimulation, BMMCs were resuspended in $150 \mu \mathrm{L}$ of $1 \times$ PBS. The cells were placed on a glass slide and left to stand for $10 \mathrm{~min}$ at room temperature. Then, the cells were fixed with $4 \%$ PFA for 15 min, blocked for $2 \mathrm{~h}$ in a solution containing $1 \%$ BSA, $5 \%$ inactivated donkey serum, and $0.1 \%$ Tween 20 , and incubated overnight with primary anti-HTT and anti-TLR-4 antibodies (1:500). The primary antibodies were removed by washing with PBS for $1 \mathrm{~min}$, ten times. Then, the slides were incubated for $2 \mathrm{~h}$ with a rat antigoat IgG (Alexa 568) antibody (1:500) and a goat anti mouse IgG (Alexa 488) antibody (1:500). The slides were incubated for 5 min with a DAPI solution (1:500) to detect cell nuclei and mounted in PVA-DABCO. The samples were observed under a Zeiss LSM-800 with Airyscan confocal microscope (Carl Zeiss, Oberkochen, Germany), using the software Zen 2.3 SP1 Blue Edition for image acquisition and analysis.

\section{Reconstitution of $c$-Kit ${ }^{\text {Wsh/Wsh }}$ mice with MCs}

Eight-week-old $c$-Kit ${ }^{W s h / W s h}$ mice were i.p. injected with $2 \times 10^{6}$ BMMCs obtained from WT or R6/1 mice as described above [12]. Briefly, mature BMMCs were resuspended in $200 \mu \mathrm{L}$ of Tyrode's buffer and injected into the peritoneal cavity of $c$-Kit ${ }^{W s h / W s h}$ mice. Further experiments on these mice, designated as Wsh Rec WT or Wsh Rec R6/1, respectively, were conducted 4 weeks after reconstitution. A successful reconstitution was defined as the restoration of the capacity of rapid ( $1 \mathrm{~h}$ after stimulus) TNF production after LPS administration $(1 \mathrm{mg} / \mathrm{kg})$ in the peritoneal cavity.

\section{Murine model of sub-lethal endotoxemia and peritoneal washes}

Mice were administered (i.p.) with either sterile isotonic saline solution $(\mathrm{SS}, 0.9 \% \mathrm{NaCl})$ or LPS $(1 \mathrm{mg} / \mathrm{kg})$. One hour after challenge, the animals were sacrificed by $\mathrm{CO}_{2}$ inhalation, and peritoneal washes were performed by injecting $2 \mathrm{~mL}$ of SS into the peritoneal cavity. The injection was followed by a gentle massage, and the fluid was recovered with a syringe after exposing the peritoneum. Peritoneal washes were centrifuged $5 \mathrm{~min}$ at $3500 \times g$, and cell-free supernatants were kept at $-80{ }^{\circ} \mathrm{C}$ until TNF quantification with a specific ELISA kit (PeproTech, 900-K54), using about $100 \mu \mathrm{L}$ of peritoneal wash and following the manufacturer's instructions.

\section{Murine model of lethal endotoxemia}

To compare the mortality of mice expressing normal or mutant Htt after LPS challenge, WT (B6CBAF1/J), R6/1 (B6CBA-Tg mice), Wsh (c-Kit $\left.{ }^{W s h / W s h}\right)$, Wsh Rec WT (c-Kit ${ }^{\text {Wh } / W s h}$ reconstituted with BMMCs derived from WT mice), and Wsh Rec R6/1 (c-Kit Wsh/Wsh reconstituted with BMMCs derived from R6/1 mice) were administered i.p. with either SS or LPS $(80 \mathrm{mg} / \mathrm{kg})$. After LPS administration, the animals were monitored for $40 \mathrm{~h}$, and survival rates were recorded as previously described [42].

\section{Statistical analysis}

The results are presented as the mean $\pm \mathrm{SD}$ of at least three independent experiments using different cell cultures. For assays in vivo, at least 4-6 animals were used for each treatment. Data from different groups and time-course curves for two treatments were analyzed by one-way or two-way analysis of variance (ANOVA), 
respectively, followed by Tukey's test. All analyses were performed with GraphPad Prism v.8 (GraphPad Software, San Diego, CA, USA).

\section{Results}

\section{Characterization of WT and R6/1 BMMCs}

To explore the effects of the expression of $\mathrm{mHtt}$ on MCs activation, BMMCs were obtained from B6CBAF1/J (WT) and transgenic B6CBA-Tg R6/1 (R6/1) mice. Although cell cultures from R6/1 mice generated about $20 \%$ less mature MCs than those from WT mice (Suppl. Fig. 1, panel a), no differences were found in mature cell viability after five weeks of culture (Suppl. Fig. 1, panel b).

The morphology of BMMCs derived from WT and R6/1 mice was analyzed with various tools. As shown in Fig. 1a, b, electronic scan microscopy revealed that mature cells from both mouse strains were similar in mean size $(9.25 \pm 1.99 \mu \mathrm{m}$ for WT cells and $9.71 \pm 1.61 \mu \mathrm{m}$ for R6/1 cells). Transmission electron microscopy showed the presence of numerous mature electrodense granules in WT and R6/1 BMMCs; no differences were found in the number of granules between genotypes (Fig. 1c, d). Since FceRI receptor expression is a proven marker of the homogeneity and maturity of a BMMC culture [43], we analyzed the expression of this receptor in BMMCs from both mouse strains by flow cytometry. As shown in Fig. 1e, no differences were observed in the expression of this receptor on the membrane of both types of cells, and over $99 \%$ of cells in both cultures were FceRIpositive. Also, when the expression of TLR-4 was assessed (Fig. 1f), the reported pattern of expression [44] was detected, and no significant differences were observed in mRNA expression for TLR-4, CD14, and MD2 among the cell types (Fig. $1 \mathrm{~g}$ ).

\section{$\beta$-hexosaminidase release was unaffected after FcદRI crosslinking, but TNF production decreased after TLR-4 activation in R6/1 BMMCs}

Then, the possible differences in FceRI-induced anaphylactic degranulation between both cell types were determined by measuring the secretion of pre-formed $\beta$ hexosaminidase when BMMCs were stimulated by IgE/ Ag complexes. After sensitization with monoclonal antiDNP IgE, the cells were incubated with the hapten dinitrophenol conjugated to human serum albumin (DNPHSA) to induce FceRI receptor crosslinking. As shown in Fig. 2a, BMMCs from WT and R6/1 mice secreted about $40 \%(43 \pm 9.21 \%$ in WT cells and $40 \pm 2.34 \%$ in R6/1 cells) of their $\beta$-hexosaminidase content in response to $27 \mathrm{ng} / \mathrm{mL}$ of antigen, with no significant
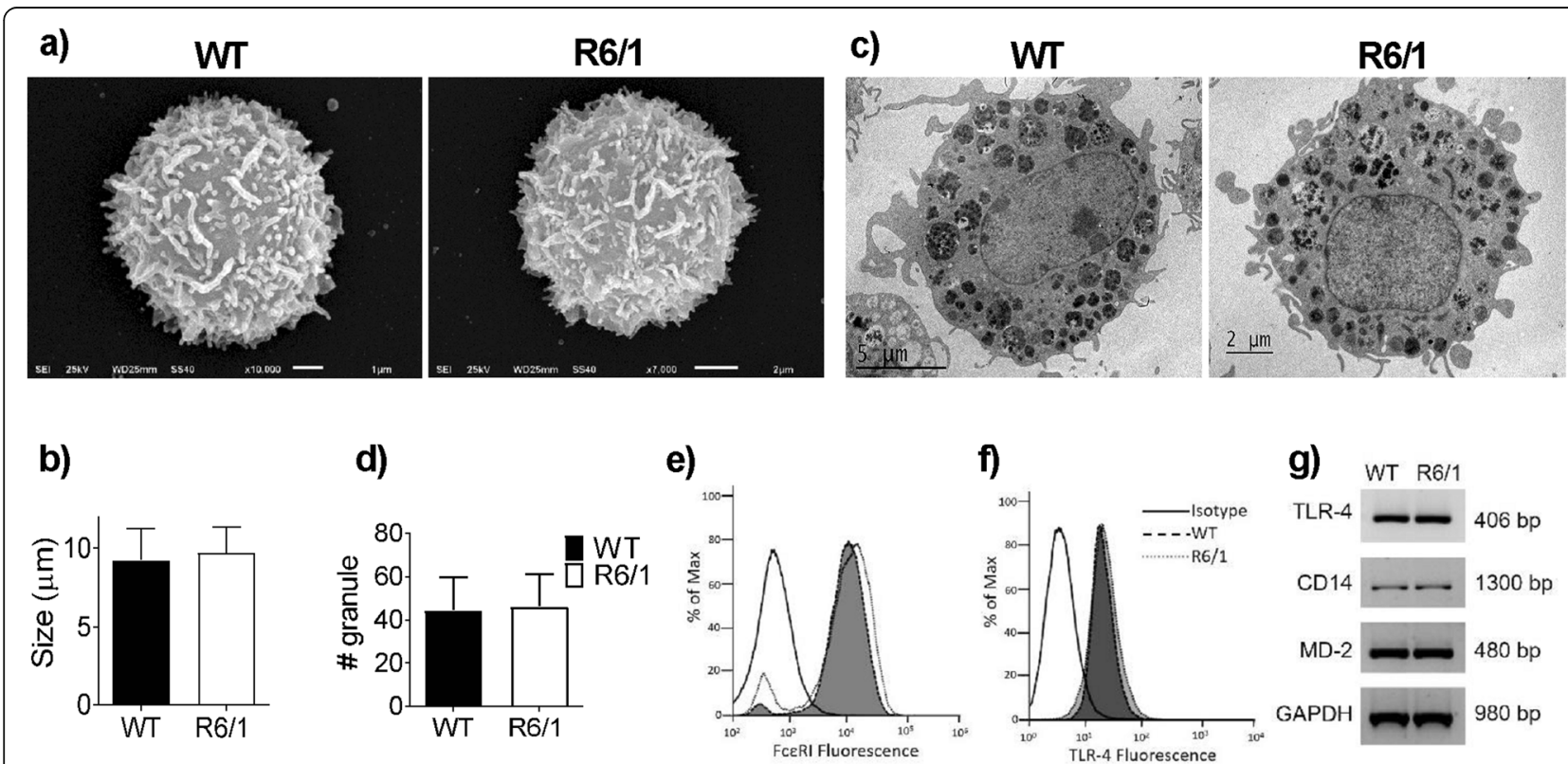

Fig. 1 Characterization of WT and R6/1 BMMCs. Bone marrow-derived mast cells from WT or R6/1 mice were cultured as described in the Methods section. a Representative electronic scanning micrograph of WT and R6/1 BMMCs (10,000X). b Mean diameter of WT-and R6/1 BMMCs. c Representative electronic transmission micrograph of WT and R6/1 BMMCs. $\mathbf{d}$ Number of granules per cell in WT and R6/1 BMMCs. e, $\mathbf{f}$ Expression of FCERI or TLR-4 receptors on the plasma membrane of WT and R6/1 BMMCs as determined by flow cytometry. $\mathbf{g}$ RT-PCR showing the expression of TLR-4, MD-2, and CD14 mRNAs in WT and R6/1 BMMCs. Analyses shown on (b) were performed by measuring 27-32 cells from at least three different cultures; analyses shown on (d) were performed by measuring 15-20 cells from at least three different cultures of each genotype by transmission electron microscopy. Data are presented as mean \pm SD. Panels $\mathbf{e}, \mathbf{f}$ show a representative flow cytometry plot from at least three experiments performed with different cell cultures. The image shown on panel $\mathbf{g}$ is representative of two experiments performed with different cell cultures 


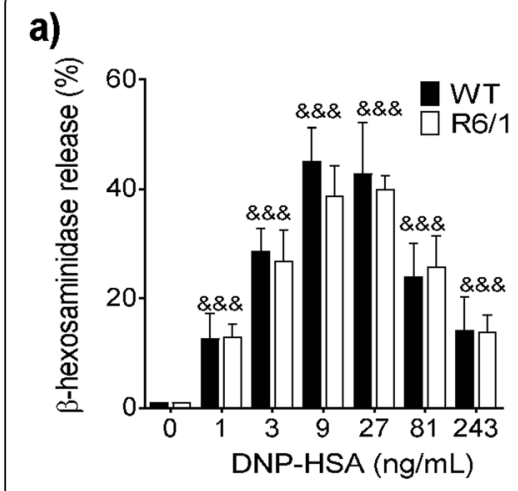

d)

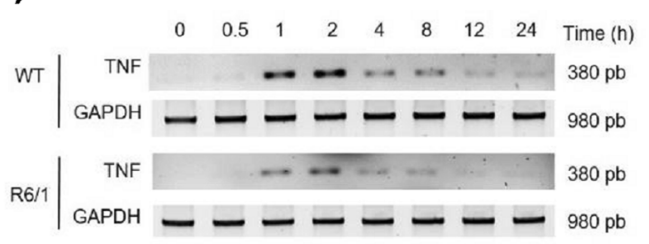

b)

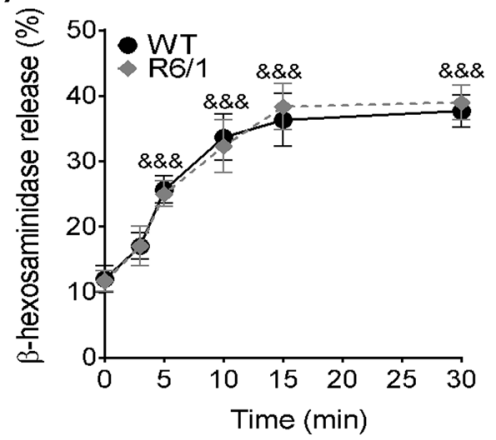

c)

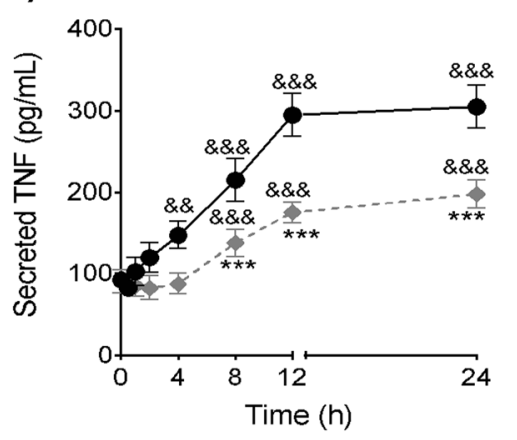

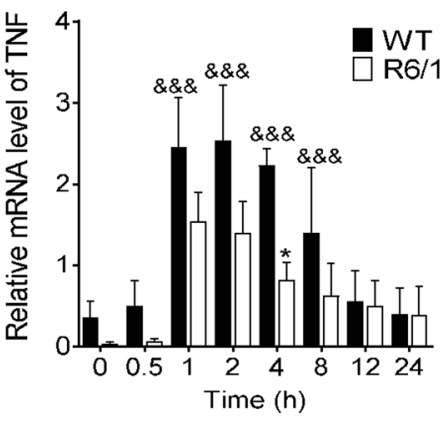

Fig. 2 FckRl-induced $\beta$-hexosaminidase release and TNF production after TLR-4 receptor activation in R6/1 BMMCs. a Dose-response curve of $\beta$ hexosaminidase release by BMMCs. b Time-course of $\beta$-hexosaminidase secretion by BMMCs after DNP-HSA (27 ng/mL) treatment. c Time-course of TNF secretion after LPS (500 ng/mL) treatment to WT and R6/1 BMMCs. TNF in cell supernatants was quantified by ELISA. d Time-course of TNF mRNA expression in WT and R6/1 cells after LPS treatment (500 ng/mL). Left panel shows a representative experiment; right panel shows densitometric analysis of different experiments. Data are presented as the mean \pm SD of at least three independent experiments performed with different cell cultures. ${ }^{*} p<0.05$, ${ }^{* *} p<0.001$ vs. WT cells; ${ }^{\& \&} p<0.01$, ${ }^{\& \&} p<0.001$ vs. the value at time zero or in non-stimulated cells, as determined by two-way ANOVA followed by Tukey's test

differences between genotypes. In a time-course experiment, both cell types secreted a maximum amount of $\beta$ hexosaminidase after $30 \mathrm{~min}$ in the presence of $27 \mathrm{ng} /$ $\mathrm{mL}$ of antigen $(38 \pm 2.51 \%$ in WT cells and $39 \pm 2.64 \%$ in R6/1 cells, Fig. 2b).

Then, the responses triggered by TLR-4 stimulation in WT and R6/1 BMMCs were studied. Since $\beta$ hexosaminidase is not released by stimulating this receptor [45], TNF production was quantified instead. BMMCs were stimulated with $500 \mathrm{ng} / \mathrm{mL}$ of E. coli LPS, and TNF secretion was measured by ELISA in a timecourse experiment. As shown in Fig. 2c, a significant TNF secretion was observed in WT BMMCs $4 \mathrm{~h}$ after LPS stimulus, and TNF concentration in supernatants reached a maximum value $(295 \pm 26.45 \mathrm{pg} / \mathrm{mL}) 12 \mathrm{~h}$ after stimulus. In contrast, LPS-induced TNF secretion in $\mathrm{R} 6 / 1 \mathrm{BMMCs}$ was only significant $8 \mathrm{~h}$ post-challenge and was lower than in WT BMMCs $(\max =197.5 \pm$ $17.07 \mathrm{pg} / \mathrm{mL}$ ) at $24 \mathrm{~h}$.

To determine whether TNF synthesis could be affected in R6/1 BMMCs, the accumulation of TNF mRNA in response to LPS was measured. As shown in Fig. 2d, an increase in TNF mRNA was observed as early as $1 \mathrm{~h}$ after LPS stimulus in WT BMMCs (a 2.4 \pm 0.60 -fold increase
$1 \mathrm{~h}$ after); this increase was sustained 2 and $4 \mathrm{~h}$ after stimulus. In contrast, a lower increase in the levels of this mRNA was observed in R6/1 cells (a $1.53 \pm 0.35$-fold increase $1 \mathrm{~h}$ after and a $0.81 \pm 0.21$-fold increase $4 \mathrm{~h}$ after).

Impaired TLR4-dependent activation of IKK, p-65, ERK1/2, and ELK-1, as well as c-fos mRNA accumulation in R6/1 BMMCs

The role of Htt in signaling pathways leading to TLR4induced TNF mRNA accumulation and TNF secretion in BMMCs was also analyzed. Previously, we had reported that TNF secretion by BMMCs after LPS stimulus requires IKK to phosphorylate the SNARE protein SNAP-23 (necessary for the fusion of TNF-containing vesicles with the plasma membrane [44]) and MAPK ERK $1 / 2$ to activate ADAM17 (the metalloproteinase that processes TNF at the plasma membrane $[44,46]$ ); therefore, we analyzed the participation of IKK and ERK $1 / 2$ in the accumulation of TNF mRNA in BMMCs. In the canonical TLR-4 signaling cascade described for dendritic cells (DCs) and macrophages, the activation of IKK and ERK1/2 controls the function of the transcription factors NFKB and ELK-1, respectively [47, 48], while $\mathrm{NF} \kappa \mathrm{B}$ has been associated with the transcription of the 
TNF gene. To test whether this could be the case for MCs, WT BMMCs were pre-treated with vehicle, the IKK inhibitor BAY117085, or the ERK1/2 inhibitor FR180204 before LPS stimulus, and a time-course experiment of TNF mRNA accumulation was conducted. As shown in Suppl. Fig. 2a, pre-incubation with BAY117085 failed to modify TLR4-triggered TNF mRNA accumulation, whereas FR180204 blocked the synthesis of TNF mRNA after LPS stimulus (Fig. S2, panel b). These results indicate that TNF mRNA accumulation after TLR-4 activation in BMMCs depends on the activity of the MAPK ERK $1 / 2$, and not significantly on the function of IKK.

Then, we analyzed the phosphorylation of IKK $\alpha / \beta$, the p65 subunit of NFKB, and ERK1/2, as well as the ensuing phosphorylation of ELK-1, in LPS-stimulated WT and R6/1 BMMCs. As shown in Fig. 3a, LPS treatment led to IKK phosphorylation in WT BMMCs 30 min after the stimulus (a 1.6-fold increase). In contrast, no significant phosphorylation was observed in cells from R6/1 mice (0.03-fold increase) at that time. A similar decrease was observed in ERK1/2 phosphorylation. WT BMMCs showed activation of that kinase $30 \mathrm{~min}$ after stimulus (1.79-fold increase), whereas this effect was not observed in R6/1 cells ( 0.27 -fold increase) at that time (Fig. 3b). On the other hand, the phosphorylation of the p65 NFkB subunit was observed in WT cells, reaching a maximum value $30 \mathrm{~min}$ after stimulus (2.62-fold increase). In contrast, significant phosphorylation was observed in R6/1 cells in basal conditions (1.78-fold increase with respect to the basal value in WT cells), and did not increase after LPS stimulus (Fig. 3c). Furthermore, ELK-1 phosphorylation was observed in response to LPS, reaching a maximum value $30 \mathrm{~min}$ after the stimulus in WT cells (4.62-fold increase) but not in

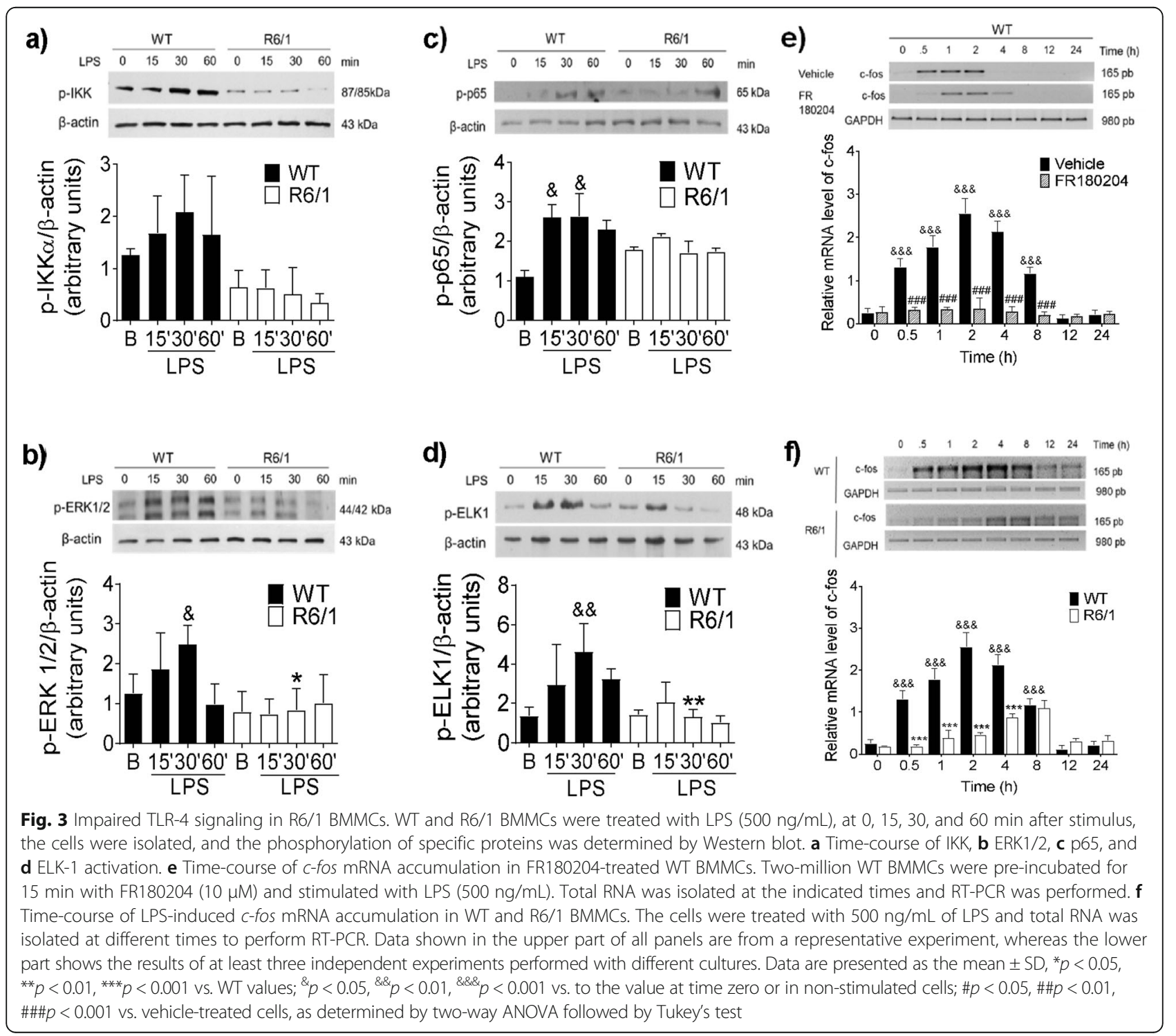


R6/1 BMMCs (Fig. 3d). A quantification of total amounts of ERK1/2, IKK, ELK-1, and p65 by Western blot revealed no differences in the quantities of those proteins between both genotypes (data not shown).

To confirm the impaired ERK1/2 activation observed in R6/1 BMMCs, the functional response dependent on ELK-1 activation was assessed by measuring the production of $c$-fos mRNA (an immediate early gene whose synthesis depends on that transcription factor [49]). First, we confirmed that the synthesis of $c$-fos mRNA depends on the activation of ERK $1 / 2$ in WT BMMCs by evaluating the effect of the ERK $1 / 2$ inhibitor FR180204 on LPS-induced $c$-fos mRNA accumulation. As shown in Fig. 3e, pre-treatment of cells with FR180204 delayed the accumulation and reduced the maximum levels of $c$ fos mRNA synthesis in LPS-stimulated WT cells. On the other hand, as expected from an impaired ERK 1/2 phosphorylation in R6/1 BMMCs, $c$-fos mRNA accumulated in WT after LPS stimulus, while this accumulation was delayed in mHtt-expressing BMMCs and it failed to reach its maximum value (Fig. 3 f). Finally, to corroborate the decrease in the activation of IKK- and ERK1/2dependent pathways induced by $\mathrm{mHtt}$ expression in BMMCs, we analyzed the TLR4-dependent synthesis of IL-10 and TGF- $\beta$, two anti-inflammatory cytokines whose synthesis relies on the activation of the transcription factors AP-1 and NFKB in immune cells [50]. As shown in Suppl. Fig. 3, a rapid accumulation of IL-10 and TGF- $\beta$ mRNAs was observed in WT BMMCs upon LPS stimulus. However, none of those mRNAs was detected at the tested times when R6/1 BMMCs were treated with LPS.

\section{Dynamin activity mediates TLR4-dependent ERK 1/2} phosphorylation, $c$-fos and TNF mRNA accumulation, and TNF secretion

Htt has been reported to participate in the signal transduction systems of several receptors [51]. Its role is

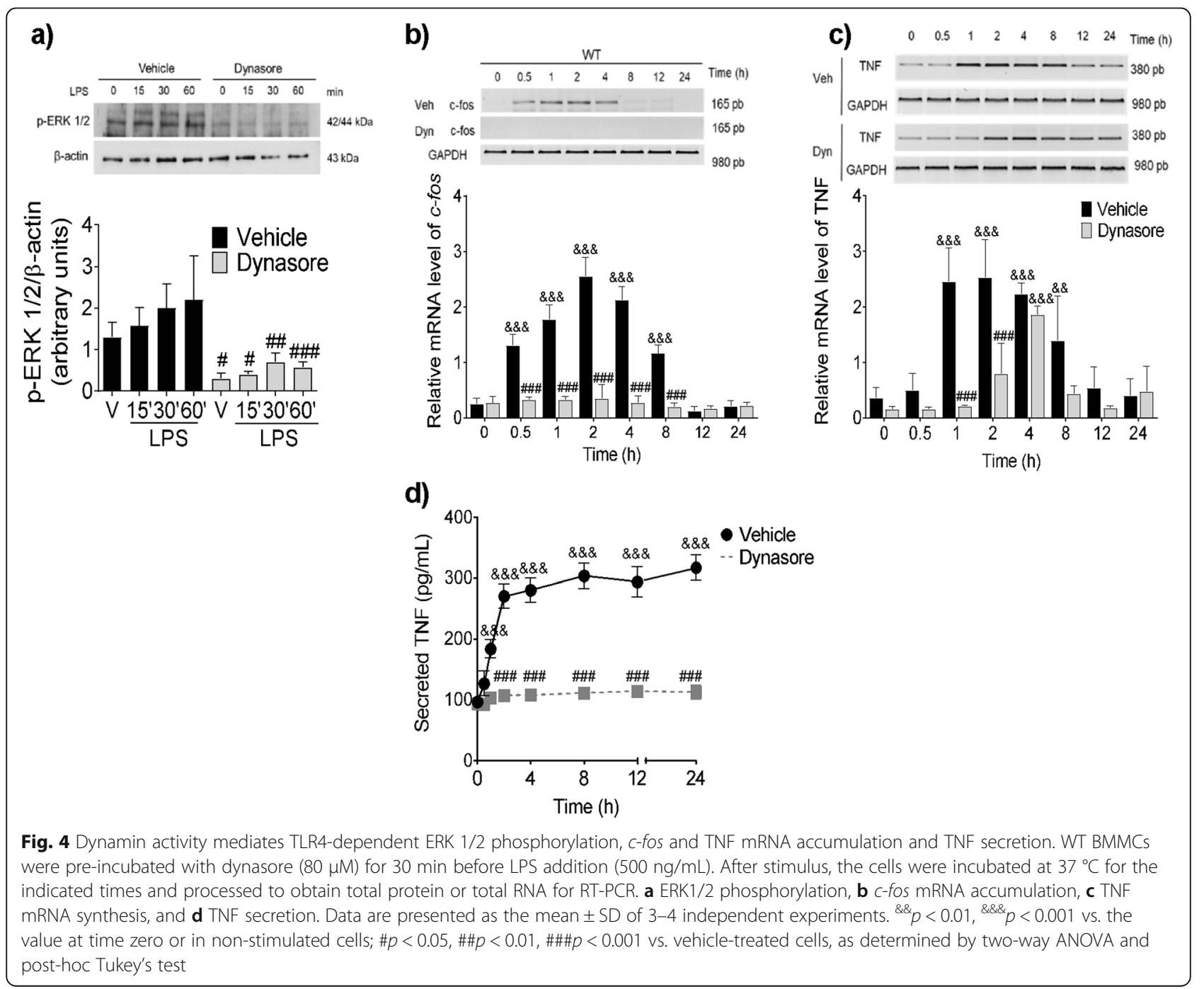


mainly related to the process of vesicular trafficking and receptor internalization required in certain cell types for kinase and transcription factor activation. For example, in striatal neurons, $\mathrm{Htt}$ contributes to the retrograde transport of the BDNF receptor TrkB, leading to ERK 1/ 2 activation and $c$-fos transcription [27]. After observing a defective ERK1/2 signaling cascade in R6/1 BMMCs, we decided to investigate whether TLR-4 vesicular trafficking was necessary for ERK $1 / 2$ activation and TNF mRNA production in WT cells, and whether these events could be affected in $\mathrm{mHtt}$-expressing BMMCs.

We tested the effect of dynasore, an inhibitor of the dynamin- and clathrin-dependent internalization [52], on the TLR4-induced activation of ERK $1 / 2$ in WT BMMCs. As shown in Fig. 4a, while LPS induced ERK
$1 / 2$ phosphorylation in vehicle-treated cells (2.2-fold increase), such effect was not observed when the cells were pre-incubated with dynasore. Dynasore pre-treatment also prevented the LPS-dependent accumulation of $c$-fos and TNF mRNAs to reach its maximum value (Fig. $4 \mathrm{~b}, \mathrm{c}$ ) and the subsequent TNF secretion in WT BMMCs (Fig. 4d).

\section{LPS treatment triggers dynamin-dependent vesicular trafficking of TLR-4 receptor in WT BMMCs}

To further analyze the possible internalization and vesicular trafficking of TLR-4 receptor in BMMCs and a potential participation of $\mathrm{Htt}$ in the phenomenon, the cellular localization of both molecules was analyzed in WT BMMCs by confocal microscopy. As shown in Fig. 5a, under basal

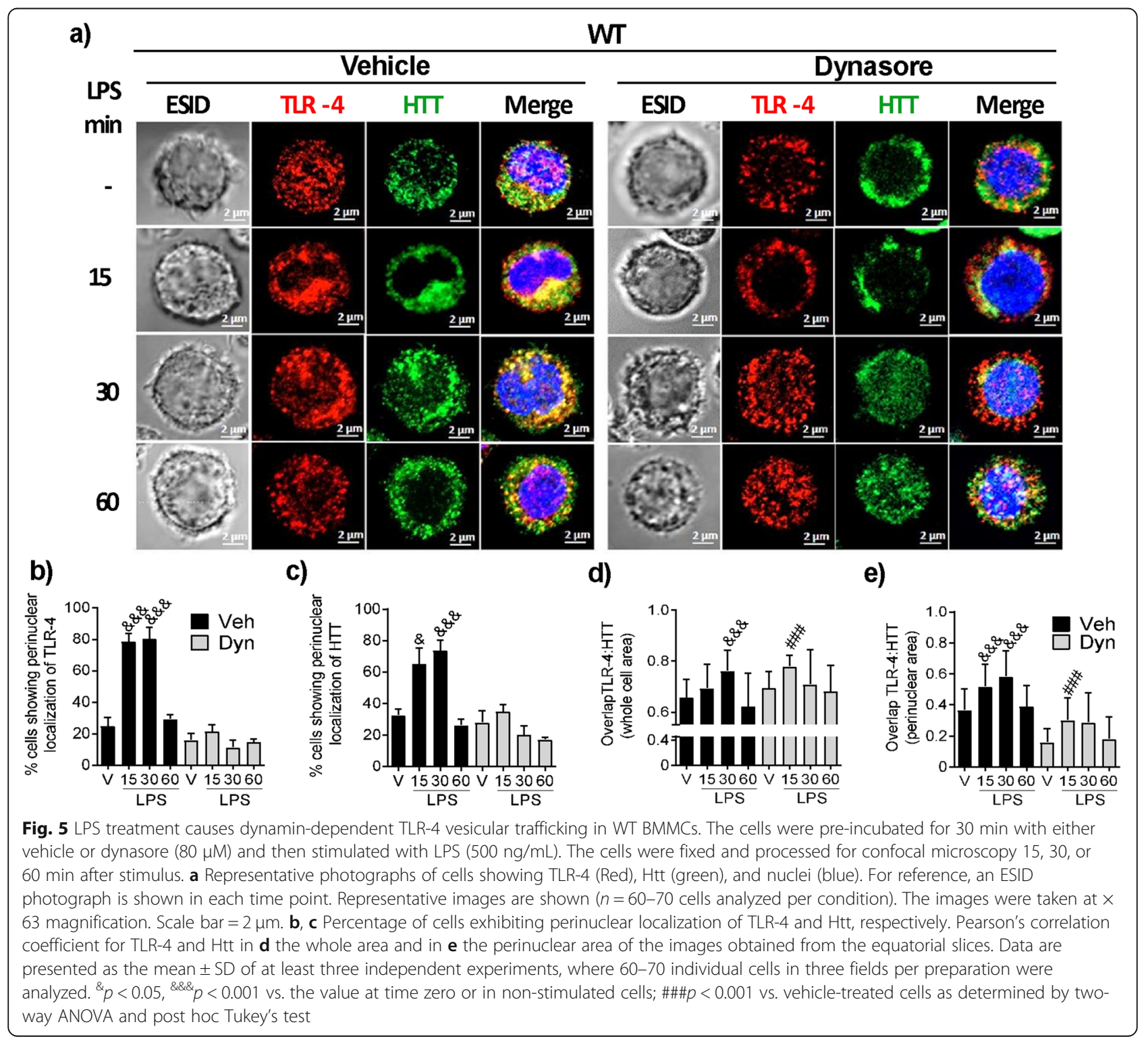


conditions, while TLR- 4 was barely found on the cell membrane of WT BMMCs, it was often detected in intracellular locations. However, 15 and $30 \mathrm{~min}$ after LPS treatment, a significant fraction of TLR-4 molecules was relocated to the perinuclear cloud in about $80 \%$ of the cells (Fig. 5b). On the other hand, in vehicle-treated cells, Htt was detected in nuclear and cytoplasmic locations, in a pattern resembling a microtubule network and associated to intracellular vesicles. After LPS stimulus, $\mathrm{Htt}$ was redistributed to the perinuclear cloud in about $80 \%$ of analyzed cells (Fig. 5 a, c).

In contrast, when the cells were pre-treated with dynasore, TLR-4 receptor was found in larger aggregates distributed throughout the cytoplasm of vehicle-treated cells. Furthermore, no significant translocation to perinuclear areas was observed upon LPS stimulus (Fig. 5a, right panel). After dynasore treatment, $\mathrm{Htt}$ was found in aggregates near to the plasma membrane and, upon LPS stimulus, its translocation to perinuclear areas was decreased in most cells (Fig. 5c).

Regarding to the association of TLR-4 and Htt in WT cells, an increased co-localization of the receptor with $\mathrm{Htt}$ (as determined by Pearson's coefficient) was observed in the whole cell area after LPS stimulus; this colocalization was not significantly affected by dynasore treatment (Fig. 5d). However, the extensive co- localization of TLR-4 and $\mathrm{Htt}$ in the perinuclear region after LPS treatment was significantly decreased by dynasore (Fig. 5e).

\section{Impaired LPS-induced TLR-4 and Htt vesicular trafficking in R6/1 BMMCs}

The hypothesis that TLR-4 receptor internalization could be affected by mHtt was tested by assessing the co-localization of Htt and TLR-4 after LPS stimulus by confocal microscopy in R6/1 BMMCs. As shown in Fig. 6a, TLR-4 was located in intracellular compartments in R6/1 cells, just like in WT BMMCs. However, the LPS-induced translocation of TLR-4 to perinuclear compartments was significantly decreased in comparison to WT BMMCs (Fig. 6b). On the other hand, an increase in the perinuclear translocation of $\mathrm{Htt}$ was observed in R6/1 cells after LPS stimulus (Fig. 6c). As expected, no significant co-localization of TLR-4 with $\mathrm{Htt}$ in the cytoplasm or perinuclear areas of R6/1 BMMCs was found (Fig. 6d, e).

\section{In vivo effects of impaired TLR-4 signaling in R6/1 mast cells}

To determine whether the impaired TNF secretion in R6/1 BMMCs could be relevant in a mast cell-

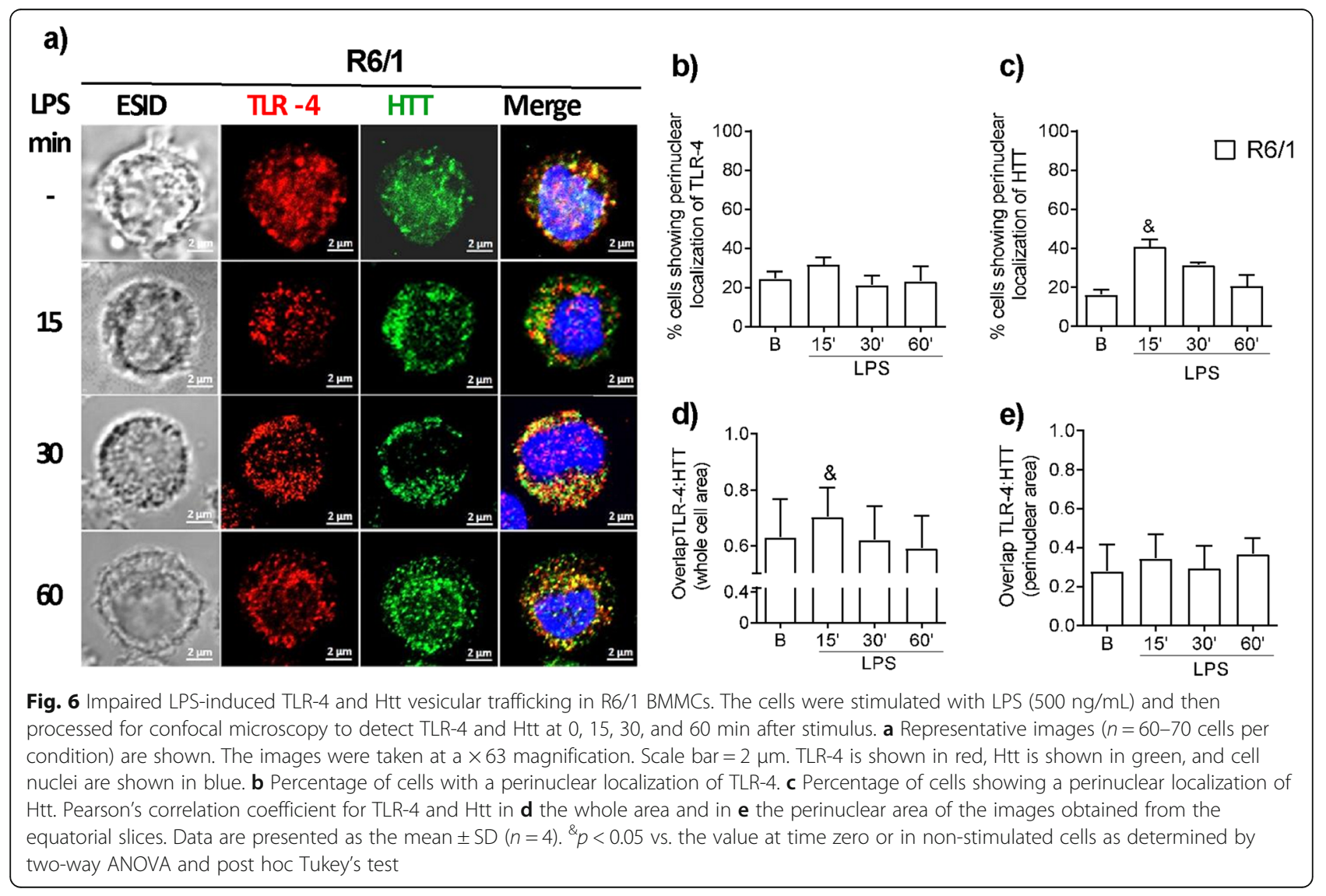



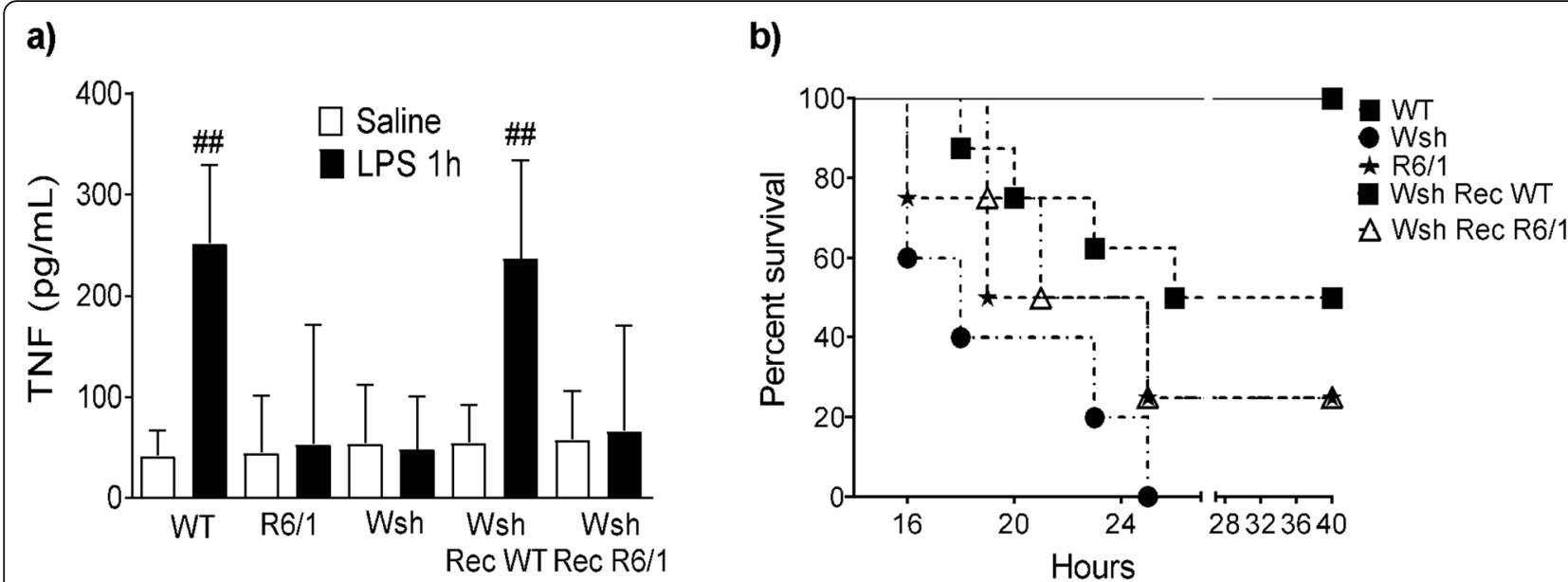

Fig. 7 In vivo effects of impaired TLR-4 signaling on R6/1 mast cells. a WT, R6/1, Wsh, Wsh reconstituted with WT BMMCs (Wsh Rec WT), and Wsh reconstituted with R6/1 BMMCs (Wsh Rec R6/1) mice were administered i.p. with either saline solution (white bars) or LPS (black bars) (1 mg/kg). One hour later, the mice were euthanized, and peritoneal washes were obtained. TNF was quantified by ELISA in peritoneal washes. Data shown in the graph were obtained from eight WT animals, six R6/1 mice, ten Wsh mice, 12 Wsh Rec WT mice, ten Wsh Rec R6/1 mice per each treatment. Data are presented as the mean \pm SD. b Same experimental groups ( 6 animals each) mentioned in (a) were i.p. administered with a sub-lethal dose of LPS $\left(80 \mathrm{mg} / \mathrm{kg}\right.$ ) and the survival was monitored for $40 \mathrm{~h}$. Each point on the lines represent the accumulated death rate. ${ }^{\# \#} p<$ 0.01 vs. vehicle-treated animals as determined by two-way ANOVA and post hoc Tukey's test

dependent TLR4-triggerd inflammatory response in vivo, the well-established model of endotoxemia by intraperitoneal administration of LPS in mice [53] was used (Fig. 7a). As previously reported, LPS administration to WT mice induced the release of TNF $(252 \pm 29.44 \mathrm{pg} /$ $\mathrm{mL} 1 \mathrm{~h}$ after stimulus). In contrast, significantly lower TNF amounts were detected in peritoneal washes from R6/1 mice after LPS stimulus $(53.3 \pm 118 \mathrm{pg} / \mathrm{mL})$. The participation of MCs in LPS-induced early TNF release was thus confirmed, since TNF was not detected in peritoneal washes from MC-deficient mice (Wsh) but it was restored in Wsh mice reconstituted with WT BMMCs (WshRecWT). However, when Wsh mice were reconstituted with BMMCs derived from R6/1 animals (WshRecR6/1), no TNF secretion was observed after LPS challenge.

To test whether impaired TNF secretion in R6/1 MCs could lead to a reduced protective reaction in sepsis, the model of endotoxemia by i.p. injection of a sub-lethal LPS dose was used [42]. Survival curves were built for WT, R6/1, Wsh, WshRecWT, and WshRecR6/1 mice after LPS administration $(80 \mathrm{mg} / \mathrm{kg})$. As shown in Fig. 7b, all WT animals survived $40 \mathrm{~h}$ after challenge, whereas $100 \%$ of Wsh mice died within $24 \mathrm{~h}$ after LPS administration. Wsh mice reconstituted with WT MCs showed an improved survival (about 50\%) after 40 h. However, R6/1 mice and Wsh mice reconstituted with R6/1 MCs showed survival rates of $25 \% 40 \mathrm{~h}$ after challenge. These results indicate that, while $\mathrm{R} 6 / 1 \mathrm{MCs}$ still contributed to the protective immune reaction against LPS administration, they were significantly less efficient than WT MCs.

\section{Discussion}

Aberrant inflammatory reactions in HD have been linked to defects in the function of innate immune cells caused by the expression of $\mathrm{mHtt}$. MCs are key players in inflammatory responses due to their capacity of secreting several pro- and anti-inflammatory mediators [6]. The production of cytokines by this cell type depends on various signaling processes that connect specific stimuli and receptor activation to cytoskeletal rearrangements, calcium mobilization, activation of transcription factors, protein synthesis, and vesicular trafficking [20]. Htt participates in processes associated to signaling like receptor internalization, kinase activation, and gene transcription in different cell types [54]. Herein, we explored the effects of the expression of $\mathrm{mHtt}$ on the function of MCs by comparing canonical mast cell-dependent responses in BMMCs derived from WT mice with mHtt-expressing R6/1 mice.

The main findings herein reported are (1) the expression of mHtt does not alter the release of $\beta$ hexosaminidase triggered by FceRI receptor in BMMCs, but it does interfere with the accumulation of IL-10, TGF- $\beta$, and TNF mRNAs and with TNF secretion mediated by TLR-4 receptor; (2) the expression of $\mathrm{mHtt}$ prevents the TLR4-mediated phosphorylation of IKK and increases the basal phosphorylation levels of the $\mathrm{NFKB}$ p65 subunit; (3) mHtt prevents the LPS-induced ERK1/2 phosphorylation, the activation of ELK-1, and the accumulation of $c$-fos mRNA, being those effects accompanied by a decrease in dynamin-dependent TLR-4 receptor vesicular trafficking; and (4) mHtt significantly impairs 
the protective, $\mathrm{MC}$-dependent innate responses triggered by TLR-4 receptor in vivo.

Culturing bone marrow cells from R6/1 mice in the presence of IL-3 and SCF produced about 20\% less mature BMMCs than those obtained from WT mice. Our results are in line with those reporting a negative influence of mHtt expression on progenitor cell differentiation, as it has been observed in the division of cortical progenitor cells and the development of the mouse neocortex [55], or in mammary stem cell division and differentiation [55]. Although differences in the initial number of progenitor cells or an altered proliferation capacity of MC precursors in R6/1 bone marrow cannot be ruled out, no differences were apparent between R6/1 mousederived mature BMMCs and those obtained from WT mice: they showed the same size and mean number of granules. Additionally, both cell phenotypes expressed FceRI and TLR-4 receptors and were able to degranulate and secrete $\beta$-hexosaminidase in response to $\mathrm{IgE} / \mathrm{Ag}$ complexes.

LPS-dependent stimulation of BMMCs results in the production of several cytokines, being TNF one of the best characterized since it is rapidly produced after TLR4 receptor triggering $[5,44,53]$. The molecular events that lead to TNF mRNA production after TLR-4 receptor stimulation have been described in innate immune cell types like macrophages and DCs [56, 57]; transcription factors like AP-1, NFKB, SP1, ELK-1, and NFAT are activated in these cell types [58]. Pre-incubating BMMCs with the IKK inhibitor BAY117085 did not affect LPSinduced TNF mRNA accumulation, but the ERK1/2 inhibitor FR180204 blocked it. Our data are consistent with those indicating that NFKB-binding sites in the TNF gene promoter are not the most relevant ones for gene transcription in MCs. Indeed, an AP-1 transcription factor complex formed by fosB, c-jun, junD, and ATF2 has been shown to bind the TNF promoter in this cell type [59]. Our results coincide with the current knowledge that ERK-dependent transcription factors, but not NFkB, participate in TNF gene transcription in MCs. For example, LPS induces TNF production through the Raf-1/MEK-MEK2/ERK1/2 pathway in monocytes [60]. On the other hand, it has been shown that the $-200 \mathrm{nt}$ proximal TNF gene promoter is capable of driving transcription in response to several stimuli, including LPS, in humans and mice [61]. Four binding sites for ETS/ELK, among other proteins (such as NFAT and Sp1), have been identified in that proximal promoter [61]. Two of the three identified NFKB binding sites are located outside the proximal promoter, and several studies have found that $\mathrm{NF \kappa B}$, while involved in TNF gene regulation, is not important as a transcription factor for TNF upon LPS challenge or other immune stimuli [58].
The expression of mHtt in R6/1 BMMCs was linked to a decreased LPS-dependent IKK phosphorylation, along with increased levels of p65 NFkB activation (as measured by its phosphorylation in the Ser-536 residue). p65 NFKB subunit (RelA) can be phosphorylated by IKK $\alpha$ or IKK $\beta$, and by IKKe or TBK-1 [62]. Our data suggest that a different kinase (other than $I K K \alpha / \beta$ ) could be involved in $\mathrm{p} 65$ phosphorylation in BMMCs, and the activation of that kinase seems to be dependent on the presence of $\mathrm{mHtt}$.

Other research groups have studied cultured cells expressing $\mathrm{mHtt}$ and striatal cells from HD transgenic mice; in contrast with our findings, those groups reported that soluble mHtt activates IKK, which in turn upregulates the NF- $\kappa B$ signaling pathway [63]. Additionally, decreasing mHtt levels by siRNA in monocytes/ macrophages from HD patients was shown to ameliorate NF- $\mathrm{kB}$ transcriptional dysregulation and downregulate the expression of pro-inflammatory cytokines [64]. Our data, however, are in agreement with those reporting that the expression of the N171-N-terminal fragment of $\mathrm{mHtt}$ (containing 82 glutamine repeats) in cultured microglial cells leads to a decreased production of proinflammatory cytokines and nitric oxide generation in response to LPS [61]. Our results strongly suggest that the expression of $\mathrm{mHtt}$ has differential effects on $\mathrm{NF}_{\kappa} \mathrm{B}$ signaling among distinct immune cell lineages. The observed impairment in TLR-4 signaling in the presence of $\mathrm{mHtt}$ was extensive to the synthesis of the mRNAs of anti-inflammatory cytokines IL-10 and TGF- $\beta$, leading to the hypothesis that by lowering the synthesis of antiinflammatory cytokines in MCs in response to innate immune stimulus, mHtt expression could contribute to the systemic pro-inflammatory phenotype observed in HD patients. Future research addressing the secretion of negative regulators of inflammation will give light in the complex immune phenotype observed in the disease.

In concordance with the decreased accumulation of TNF mRNA after LPS stimulus, mHtt-expressing BMMCs showed an impaired activation of the TLR4dependent ERK1/2-ELK1-cFos axis. Remarkably, the activation of that signaling cascade in WT cells required dynamin-dependent TLR-4 receptor vesicular trafficking. Our results are in line with those studies indicating that the activity of dynamin is necessary for the activation of that kinase [65]. For example, dynasore blocks CCL2 and phorbol-myristate acetate-induced ERK1/2 activation in a step located between PKC and that MAPK in HEK293 cells [65], suggesting that intracellular vesicle trafficking is coupled to the formation of the activation complex of MAPK triggered by distinct receptors. Also, dynamin-dependent internalization seemed to be required even for basal ERK1/2 phosphorylation in MCs, because dynasore treatment significantly decreased the 
phosphorylation rates of that kinase. Since BMMCs used in this study were sensitized with IgE and it has been shown that monomeric IgE slightly increases the basal phosphorylation of ERK1/2 [66], our results indicate that ERK1/2 activation after FceRI receptor triggering by monomeric IgE could also require intracellular, dynamin-dependent, vesicle trafficking.
Regarding to the defective LPS-induced ERK1/2 activation in mHtt expressing BMMCs, our results are in concordance with previous studies reporting that $\mathrm{Htt}$ participates in MAPK activation (specifically on ERK1/2dependent pathway) [67, 68]. In particular, our data strongly suggest that $\mathrm{Htt}$ plays a similar role in receptor internalization and retrograde transport of specific

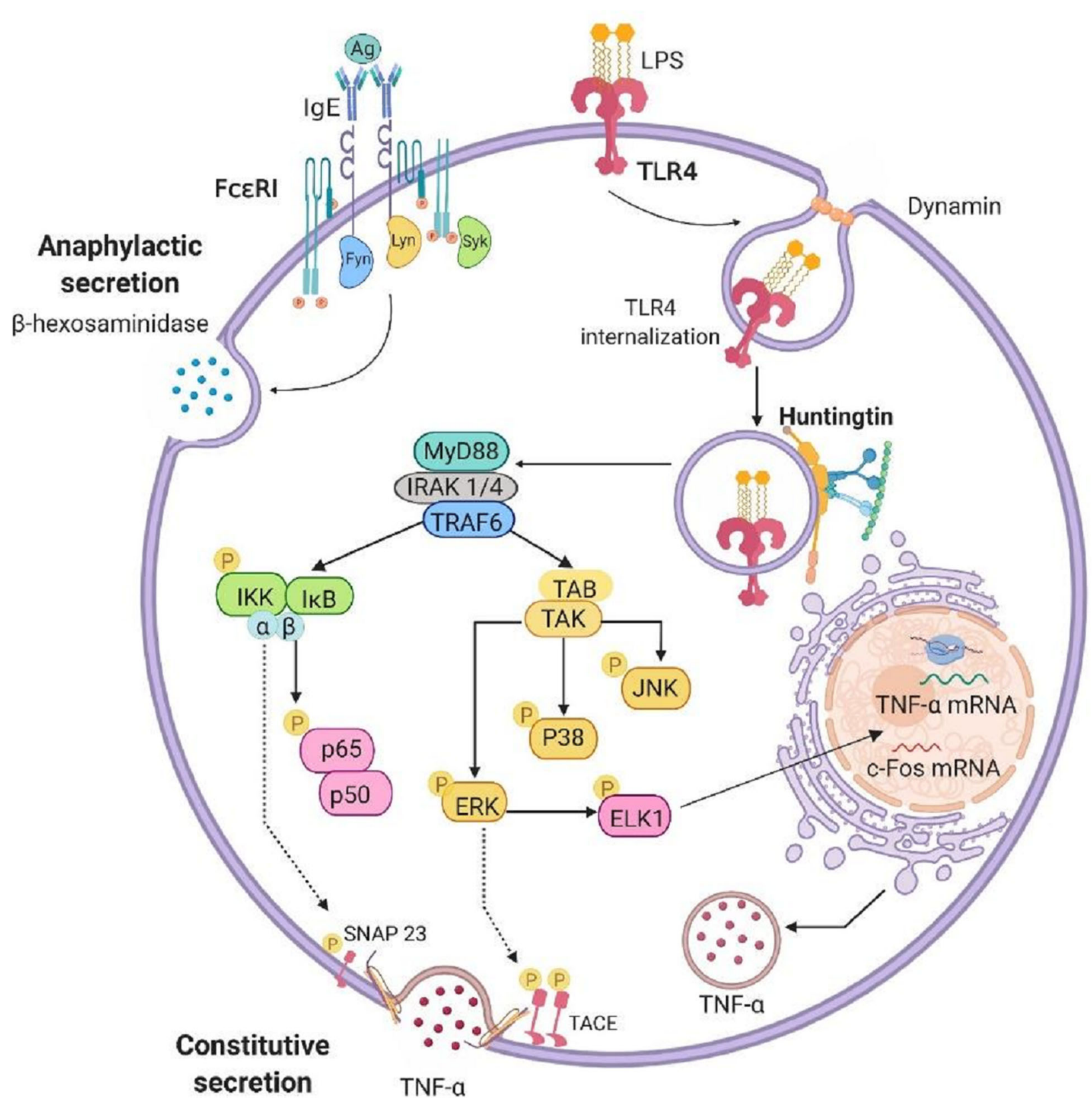

Fig. 8 Pleiotropic functions of Htt in the TLR-4 signal transduction system in BMMCs. Upon LPS stimulus, TLR-4 is translocated to the perinuclear area in Htt-containing vesicles by a mechanism depending on the activity of dynamin. This process leads to the activation of the ERK1/2-ELK-1 signaling pathway, which is involved in the accumulation of $c$-fos and TNF mRNAs, along with the secretion of TNF via TACE activation. The expression of $\mathrm{mHtt}$ in BMMCs not only impairs the ERK1/2 signaling cascade, but also decreases IKK phosphorylation, which has been associated with the phosphorylation of SNAP23 and TNF secretion upon TLR-4 triggering in this cell type. Anaphylactic degranulation triggered by FcERI seems to be independent on the function of $\mathrm{Htt}$ 
receptors in MCs to that observed in striatal neurons, where $\mathrm{Htt}$ participates in the retrograde transport of the TrkB receptor, required for ERK1/2 activation and $c$-fos transcription [27].

Our results show that TLR-4 is mainly located in the cytoplasm of BMMCs, and it is translocated to perinuclear zones upon LPS stimulus. Those regions have been proposed to form a "perinuclear cloud" [69] where endosomes are recycled and redistributed to various cell compartments. Our data are in line with those reported by Okumura et al. (2003) showing that, although TLR-4 can be detected in the plasma membrane by flow cytometry, it is mainly located in the cytoplasm of peripheral blood-derived and lung human MCs. Interestingly, TLR4 receptor was found near the cell nucleus in those cellular preparations [70]. Also, an intracellular location of TLR-4 was observed by confocal microscopy in the human MC line HMC-1 [71], and a low membrane expression of that receptor was found in bone marrow-derived macrophages, being this membrane expression significantly decreased $2 \mathrm{~h}$ after LPS treatment [72]. Finding TLR-4 receptor in this location of BMMCs is also consistent with that reported for peripheral blood-derived DCs, where this receptor is not detected on the plasma membrane; instead, it is found in a tubo-vesicular pattern that is more intense in a region near the nucleus, associated with the Golgi apparatus and co-localized with $\alpha$-tubulin. In DCs, microtubules have been suggested to act as transport tracks for TLR vesicles [73].

Internalization of TLR-4 receptor has been associated to the activation of the TRIF/TRAM-dependent signaling cascade [69, 74] in monocytes and dendritic cells. The current model for TLR-4 signal transduction pathway proposes the activation of the MyD88/TIRAPdependent MAPK and IKK phosphorylation from the plasma membrane before receptor endocytosis, which is necessary for a second wave of gene transcription depending on IRF3 [72]. Our results indicating that a dynamin-mediated vesicular trafficking or of TLR-4 receptor is needed for ERK1/2 and ELK-1 activation, together with $c$-fos mRNA transcription in BMMCs deepens our knowledge on the signal transduction pathways triggered by LPS in these cells, in which a lack of the TRIF/TRAM-mediated TLR-4 signaling axis has been reported [72]. Altogether, our data support the notion that an intracellular location of TLR-4 receptor does not necessarily lead to TRIF-TRAM-dependent events but is required for the MyD88-dependent pathway to function [75].

R6/1 mice and Wsh mice reconstituted with R6/1 BMMCs failed to show the MC-dependent early TNF production after i.p. injection of LPS, showing that the impaired activity in R6/1 MCs are observable in vivo. Since TNF derived from MCs (unlike other cell types) has been associated to a protective response against gram-negative bacterial infections in mice $[5,76,77]$, the impaired production of TNF resulted in an increased mortality in R6/1 mice and Wsh mice reconstituted with R6/1 BMMCs after a sub-lethal LPS dose. This result suggests that the expression of $\mathrm{mHtt}$ significantly impairs early, MCdependent, innate immunity responses to TLR-4 receptor ligands in vivo.

Recent data supports a significant role of MCs on neuroinflammation, since stabilization of brain MCs diminish LPS-induced microglial activation [78], suggesting that TLR-4 receptor expressed in MCs could be an important element in the regulation inflammatory reactions in the brain. Our data suggest that the expression of $\mathrm{mHtt}$ alters MC-driven inflammatory reactions that could be relevant to $\mathrm{HD}$ and other neurodegenerative diseases.

\section{Conclusions}

This work shows, for the first time, that the expression of $\mathrm{mHtt}$ alters the internalization of TLR-4 receptor, required for the activation of the ERK1/2-Elk1-c-Fos signaling axis in MCs. Thus, mHtt expression blocks the TLR4-dependent synthesis of pro-and anti-inflammatory cytokines in that cell type (Fig. 8), affecting MCdependent inflammatory reactions in vivo. Finally, our data suggest a significant impairment in innate immunitytriggered responses of $\mathrm{MCs}$ that express $\mathrm{mHtt}$, which could contribute to the altered inflammatory phenotype observed in HD patients.

\section{Supplementary information}

Supplementary information accompanies this paper at https://doi.org/10. 1186/s12974-020-01758-9.

Additional file 1: FigureS1. Growth of bone marrow cultures and cell viability of WT and R6/1 BMMCs. a) Total bone marrow from tibias and femurs from WT and R6/1 mice was seeded in a T75 flask with RPMI medium, supplemented with IL-3 and cultured as described in the Methods section. Cells in culture supernatants were counted. Data are presented as the mean \pm SD from at least 20 cultures obtained from the same number of mice. b) One million BMMCs of each genotype were resuspended in $1 \mathrm{~mL}$ of supplemented RPMI, mixed with the Muse ${ }^{\mathrm{TM}}$ Count Viability Kit reagent (Millipore) and analyzed for viability with the Muse $\mathrm{T}^{\mathrm{TM}}$ Cell Analyzer. ${ }^{* * *} p<0.001$ vs. WT values; $\& \& \& p<0.001$ vs. the value at time zero or in non-stimulated cells as determined by two-way ANOVA and post hoc Tukey's test.

Additional file 2: Figure S2. Effect of inhibition of IKK or ERK1/2 on LPS-induced TNF mRNA synthesis. WT BMMCs were pre-incubated for 15 min at $37^{\circ} \mathrm{C}$ with a) BAY117085 (10 $\left.\mu \mathrm{M}\right)$ or b) FR180204 $(10 \mu \mathrm{M})$ and then stimulated with LPS (500 ng/mL). The cells were collected at different times post-stimulus and total RNA was extracted to detect TNF mRNA by RT-PCR. The upper part of each panel shows a representative image from at least three independent experiments, while TNF mRNA accumulation is shown in the lower panel. Data are presented as the mean \pm SD from at least three independent experiments performed with different cell cultures. $\& p<0.05, \& \& p<0.01$, vs. the value at time zero or in non- 
stimulated cells; $\# p<0.05$ vs. vehicle-treated cells as determined by twoway ANOVA followed by Tukey's test.

Additional file 3: Figure S3. $\mathrm{mHtt}$ expression prevents TLR4-triggered IL-10 and TGF- $\beta$ mRNA synthesis. a) Time-course of IL-10 mRNA expression in WT and R6/1 cells in response to LPS. b) Time-course of TGF- $\beta$ mRNA expression in WT and R6/1 cells in response to LPS. Upper panels show an image obtained from a representative experiment, and lower panels show densitometric analysis of different experiments. Data are presented as the mean $\pm S D$ from at least three experiments performed with independent cultures. ${ }^{*} p<0.05,{ }^{* *} p<0.01,{ }^{* *} p<0.001$ vs. WT values; $\& p<0.05, \& \& p<0.01, \& \& \&<0.001$ vs. the value at time zero or in non-stimulated cells as determined by two-way ANOVA followed by Tukey's test.

\section{Abbreviations}

BMMC: Bone marrow-derived mast cells; DAMPs: Damage-associated molecular patterns; DCs: Dendritic cells; ELK1: ETS transcription factor; ERK: Extracellular-signal-regulated kinase; FceRl: High-affinity lgE receptor; HD: Huntington's disease; Htt: Huntingtin; IKK: IkB kinase; IL-10: Interleukin 10; IL-3: Interleukin 3; IL-6: Interleukin 6; LPS: Lipopolysaccharide; mHtt: Mutated Huntingtin; NFkB: Nuclear factor kappa-light-chain-enhancer of activated B cells; PAMPs: Pathogen-associated molecular patterns; TGF $\beta$ : Transforming growth factor beta; TLR4: Toll-like receptor 4; TNF: Tumor necrosis factor; Wsh: MC-deficient c-Kit Wsh Wsh

\section{Acknowledgments}

The authors thank María de Lourdes Rojas Morales from the Electron Microscopy Unit, Cinvestav; M.Sc. Victor Hugo Rosales García from the Flow Cytometry Unit, Cinvestav, for his assistance on the use of the flow cytometer; Dr. René Garduño Gutiérrez from Cinvestav Sur for his assistance on the use of the confocal microscope; Ing. Isaac Villalpando Ricaño for his assistance with the applications and programs required for data analysis; Dr. Jorge Fernández Hernández, Ma. Antonieta López-López, Ricardo Gaxiola Centeno, Víctor Manuel García Gómez, and Benjamín E. Chávez-Álvarez from the Unit for Production and Experimentation with Laboratory Animals, UPEAL, Cinvestav for their assistance in maintaining the c-Kit WshWsh mice used in this study. Juan Francisco Rodriguez proofread the final draft of the manuscript. Juan Martínez Parente and Ramón Martínez Gómez from the Animal Facility of the Pharmacobiology Department for his help in the maintenance of $\mathrm{WT}$ and R6/1 colonies of mice.

\section{Authors' contributions}

M.J.P.-R. performed most of the experiments, analyzed data, contributed to discussion, and wrote the first manuscript draft. R.-F.A. and I.-S.A. performed experiments and contributed to the analysis and discussion of results; P.-S.F. contributed to the design of experiments and result discussion, and provided R6/1 and WT mice used in the study; G.-E.C. designed the main experiments, contributed to data analysis and discussion, wrote the final manuscript draft and was responsible of the grant that financed the study. The authors read and approved the final manuscript.

\section{Funding}

This project was supported by the National Council of Science and Technology (Conacyt), Mexico, grant No. Conacyt-FC-1122 to C.G.-E., and the scholarship No. 29588 to M.J.P.-R.

\section{Availability of data and materials}

All datasets generated and/or analyzed in this study are available from the corresponding author on reasonable request.

\section{Ethics approval and consent to participate}

All procedures involving animals were approved by the Cinvestav Institutional Ethics Committee (protocols 074-13 and 00137-15) and were performed in accordance with the Mexican Official Norm for the Use and Care of Laboratory animals (NOM-062-ZOO-1999).

\section{Consent for publication}

Not applicable.

\section{Competing interests}

The authors declare that they have no competing interests.

\section{Author details}

${ }^{1}$ Departamento de Farmacobiología, Centro de Investigación y de Estudios Avanzados del IPN, Calzada de los Tenorios 235, Granjas Coapa, Tlalpan, 14330 Mexico City, Mexico. ${ }^{2}$ Laboratorio de Neurofarmacología Molecular y Nanotecnología, Instituto Nacional de Neurología y Neurocirugía "Manuel Velasco Suárez", Insurgentes Sur 3877, La Fama, Tlalpan, 14269 Mexico City, Mexico.

Received: 6 December 2019 Accepted: 24 February 2020

Published online: 27 March 2020

\section{References}

1. Ross CA, Aylward EH, Wild EJ, Langbehn DR, Long JD, Warner JH, et al. Huntington disease: natural history, biomarkers and prospects for therapeutics. Nat Rev Neurol Nature Publishing Group. 2014;10:204-16.

2. Rocha NP, Ribeiro FM, Furr-Stimming E, Teixeira AL. Neuroimmunology of Huntington's disease: revisiting evidence from human studies. Mediat Inflamm. 2016;2016:8653132.

3. Gentek R, Ghigo C, Hoeffel G, Bulle MJ, Msallam R, Gautier G, et al. Hemogenic endothelial fate mapping reveals dual developmental origin of mast cells. Immunity. 2018:48:1160-71. e5.

4. Metcalfe DD, Dc W. ASH 50th anniversary review mast cells and mastocytosis. World Health. 2012;112:946-56.

5. Supajatura V, Ushio H, Nakao A, Okumura K, Ra C, Ogawa H. Protective roles of mast cells against enterobacterial infection are mediated by toll-like receptor 4. J Immunol. 2001;167:2250-6.

6. Galli SJ, Nakae S, Tsai M. Mast cells in the development of adaptive immune responses. Nat Immunol. 2005;6:135-42.

7. St. John AL, Abraham SN. Innate immunity and its regulation by mast cells. J Immunol 2013;190:4458-4463.

8. Beghdadi W, Madjene LC, Benhamou M, Charles N, Gautier G, Launay P, et al. Mast cells as cellular sensors in inflammation and immunity. Front Immunol. 2011;2:1-15.

9. Jones MK, Nair A, Gupta M. Mast cells in neurodegenerative disease. Front Cell Neurosci. 2019;13:1-9.

10. Abraham SN, St. John AL. Mast cell-orchestrated immunity to pathogens. Nat Rev Immunol. Nature Publishing Group. 2010;10:440-52.

11. Hoshino K, Takeuchi O, Kawai T, Sanjo H, Ogawa T, Takeda Y, et al. Cutting edge: toll-like receptor 4 (TLR4)-deficient mice are hyporesponsive to lipopolysaccharide: evidence for TLR4 as the Lps gene product. J Immunol. 1999:162:3749-52.

12. Madera-Salcedo IK, Cruz SL, Gonzalez-Espinosa C. Morphine decreases early peritoneal innate immunity responses in Swiss-Webster and C57BL6/J mice through the inhibition of mast cell TNF-a release. J Neuroimmunol. 2011;232:101-7.

13. Doyle SL, O'Neill LAJ. Toll-like receptors: from the discovery of NFKB to new insights into transcriptional regulations in innate immunity. Biochem Pharmacol. 2006;72:1102-13.

14. Sandig $H$, Bulfone-Paus $S$. TLR signaling in mast cells: common and unique features. Front Immunol. 2012;3:1-13.

15. Fujioka S, Niu J, Schmidt C, Sclabas GM, Peng B, Uwagawa T, et al. NF-kB and AP-1 connection: mechanism of NF-KB-dependent regulation of AP-1 activity. Mol Cell Biol. 2004;24:7806-19.

16. Castle JD, Guo Z, Liu L. Function of the t-SNARE SNAP-23 and secretory carrier membrane proteins (SCAMPs) in exocytosis in mast cells. Mol Immunol. 2002;38:1337-40.

17. Duque GA, Descoteaux A. Macrophage cytokines: involvement in immunity and infectious diseases. Front Immunol. 2014;5:1-13.

18. Pascual-Lucas M, Fernandez-Lizarbe S, Montesinos J, Guerri C. LPS or ethanol triggers clathrin- and rafts/caveolae-dependent endocytosis of TLR4 in cortical astrocytes. J Neurochem. 2014;129:448-62.

19. Praefcke GJK, McMahon HT. The dynamin superfamily: universal membrane tubulation and fission molecules? Nat Rev Mol Cell Biol. 2004;5:133-47.

20. Wernersson S, Pejler G. Mast cell secretory granules: armed for battle. Nat Rev Immunol. 2014;14:478-94.

21. Saudou F, Humbert S. The biology of Huntingtin. Neuron. 2016;89:910-26.

22. Caviston JP, Ross JL, Antony SM, Tokito M, Holzbaur ELF. Huntingtin facilitates dynein/dynactin-mediated vesicle transport. Proc Natl Acad Sci U S A. 2007;104:10045-50. 
23. Gunawardena S, Her LS, Brusch RG, Laymon RA, Niesman IR, Gordesky-Gold $B$, et al. Disruption of axonal transport by loss of huntingtin or expression of pathogenic polyQ proteins in Drosophila. Neuron. 2003;40:25-40.

24. McGuire JR, Rong J, Li SH, Li XJ. Interaction of Huntingtin-associated protein-1 with kinesin light chain: implications in intracellular trafficking in neurons. J Biol Chem. 2006:281:3552-9.

25. Zala D, Hinckelmann MV, Saudou F. Huntingtin's function in axonal transport is conserved in Drosophila melanogaster. PLoS One. 2013:8:1-10.

26. Wong YC, Holzbaur ELF. The regulation of autophagosome dynamics by Huntingtin and HAP1 is disrupted by expression of mutant Huntingtin, leading to defective cargo degradation. J Neurosci. 2014;34:1293-305.

27. Liot G, Zala D, Pla P, Mottet G, Piel M, Saudou F. Mutant Huntingtin alters retrograde transport of TrkB receptors in striatal dendrites. J Neurosci. 2013; 33:6298-309.

28. Gauthier LR, Né B, Charrin DC, Borrell-Pagè M, Dompierre JP, Lè Ne Rangone $H$, et al. Huntingtin controls neurotrophic support and survival of neurons by enhancing BDNF vesicular transport along microtubules. Cell. 2004;14:478-94

29. Colin E, Zala D, Liot G, Rangone H, Borrell-Pagès M, Li XJ, et al. Huntingtin phosphorylation acts as a molecular switch for anterograde/retrograde transport in neurons. EMBO J. 2008;27:2124-34.

30. Twelvetrees AE, Yuen EY, Arancibia-Carcamo IL, MacAskill AF, Rostaing P, Lumb MJ, et al. Delivery of GABAARs to synapses is mediated by HAP1-KIF5 and disrupted by mutant Huntingtin. Neuron. 2010;65:53-65.

31. Mangiarini L, Sathasivam K, Seller M, Cozens B, Harper A, Hetherington C, et al. Exon 1 of the HD gene with an expanded CAG repeat is sufficient to cause a progressive neurological phenotype in transgenic mice. Cell. 1996; 87:493-506.

32. Martín-Ávila A, Medina-Tamayo J, Ibarra-Sánchez A, Vázquez-Victorio G, Castillo-Arellano J, Hernández-Mondragón AC, et al. Protein tyrosine kinase Fyn regulates TLR4-elicited responses on mast cells controlling the function of a PP2A-PKCa/ $\beta$ signaling node leading to TNF secretion. J Immunol. 2016;196:5075-88

33. Chowdhury P, Sacks SH, Sheerin NS. Toll-like receptors TLR2 and TLR4 initiate the innate immune response of the renal tubular epithelium to bacterial products. Clin Exp Immunol. 2006;145:346-56.

34. Ushio H, Nakao A, Supajatura V, Miyake K, Okumura K, Ogawa H. MD-2 is required for the full responsiveness of mast cells to LPS but not to PGN. Biochem Biophys Res Commun. 2004;323:491-8.

35. Lee JD, Kato K, Tobias PS, Kirkland TN, Ulevitch RJ. Transfection of CD14 into 70Z/ 3 cells dramatically enhances the sensitivity to complexes of lipopolysaccharide (LPS) and LPS binding protein. J Exp Med. 1992;175:1697-705.

36. Dasgupta S, Jana M, Zhou Y, Fung YK, Ghosh S, Pahan K. Antineuroinflammatory effect of NF-kB essential modifier-binding domain peptides in the adoptive transfer model of experimental allergic encephalomyelitis. J Immunol. 2004;173:1344-54.

37. Adebanjo OA, Moonga BS, Yamate T, Sun L, Minkin C, Abe E, et al. Mode of action of interleukin- 6 on mature osteoclasts. Novel interactions with extracellular Ca2+ sensing in the regulation of osteoclastic bone resorption. J Cell Biol. 1998;142:1347-56.

38. Jin X, Liao Y, Tan X, Guo J, Wang G, Zhao F, et al. Involvement of the p38 MAPK signaling pathway in overexpression of matrix metalloproteinase-9 during the course of brain edema in 1,2-dichloroethane-intoxicated mice. Neurotoxicology Elsevier. 2018;69:296-306.

39. Gonzalez-Espinosa C, Odom S, Olivera A, Hobson JP, Cid Martinez ME, Oliveira-dos-Santos A, et al. Preferential signaling and induction of allergypromoting lymphokines upon weak stimulation of the high affinity lgE receptor on mast cells. J Exp Med. 2003;197:1453-65.

40. Parravicini V, Gadina M, Kovarova M, Odom S, Gonzalez-Espinosa C, Furumoto $Y$, et al. Fyn kinase initiates complementary signals required for IgE-dependent mast cell degranulation. Nat Immunol. 2002;3:741-8.

41. Medina-Tamayo J, Ibarra-Sánchez A, Padilla-Trejo A, González-Espinosa C. IgE-dependent sensitization increases responsiveness to LPS but does not modify development of endotoxin tolerance in mast cells. Inflamm Res. 2011;60:19-27.

42. Melo ES, Barbeiro HV, Ariga S, Goloubkova T, Curi R, Velasco IT, et al. Immune cells and oxidative stress in the endotoxin tolerance mouse model. Br J Med Biol Res. 2010;43:57-67.

43. Dahlin JS, Ding Z, Hallgren J. Distinguishing mast cell progenitors from mature mast cells in mice. Stem Cells Dev. 2015;24:1703-11.

44. Madera-Salcedo IK, Cruz SL, Gonzalez-Espinosa C. Morphine prevents lipopolysaccharide-induced TNF secretion in mast cells blocking IkB kinase activation and SNAP-23 phosphorylation: correlation with the formation of a B-Arrestin/TRAF6 complex. J Immunol. 2013;191:3400-9.

45. Fukuishi N, Murakami S, Ohno A, Yamanaka N, Matsui N, Fukutsuji K, et al. Does $\beta$-Hexosaminidase function only as a degranulation Indicator in mast cells? The primary role of $\beta$-Hexosaminidase in mast cell granules. J Immunol. 2014;193:1886-94.

46. Guzmán-Mejía F, López-Rubalcava C, González-Espinosa C. Stimulation of nAchRa7 receptor inhibits TNF synthesis and secretion in response to LPS treatment of mast cells by targeting ERK1/2 and TACE activation. J Neuroimmune Pharmacol. 2018;13:39-52.

47. Zhang FX, Kirschning CJ, Mancinelli R, Xu XP, Jin Y, Faure E, et al. Bacterial lipopolysaccharide activates nuclear factor-kB through interleukin-1 signaling mediators in cultured human dermal endothelial cells and mononuclear phagocytes. J Biol Chem. 1999;274:7611-4.

48. Lu YC, Yeh WC, Ohashi PS. LPS/TLR4 signal transduction pathway. Cytokine. 2008:42:145-51.

49. Cavigelli M, Dolfi F, Claret FX, Karin M. Induction of c-fos expression through JNK-mediated TCF/Elk-1 phosphorylation. EMBO J. 1995;14:5957-64.

50. Mosser DM, Zhang X. Interleukin-10: new perspectives on an old cytokine. Immunol Rev. 2008;226:205-18.

51. László B, Lawrence M. A novel target for Huntington's disease: ERK at the crossroads of signaling: The ERK signaling pathway is implicated in Huntington's disease and its upregulation ameliorates pathology. Bioessays. 2012;34:142-8.

52. Macia E, Ehrlich M, Massol R, Boucrot E, Brunner C, Kirchhausen T. Dynasore, a cell-permeable inhibitor of Dynamin. Dev Cell. 2006;10:839-50.

53. Avila M, Martinez-Juarez A, Ibarra-Sanchez A, Gonzalez-Espinosa C. Lyn kinase controls TLR4-dependent IKK and MAPK activation modulating the activity of TRAF-6/TAK-1 protein complex in mast cells. Innate Immun. 2012;18:648-60.

54. Li SH, Li XJ. Huntingtin-protein interactions and the pathogenesis of Huntington's disease. Trends Genet. 2004;20:146-54.

55. Molina-Calavita M, Barnat M, Elias S, Aparicio E, Piel M, Humbert S. Mutant huntingtin affects cortical progenitor cell division and development of the mouse neocortex. J Neurosci. 2014:34:10034-40.

56. Zuckerman SH, Shellhaas J, Butter LD. Differential regulation of lipopolysaccharide-induced interleukin 1 and tumor necrosis factor synthesis: effects of endogenous and exogenous glucocorticoids and the role of the pituitary-adrenal axis. Eur J Immunol. 1989;19:301-5.

57. Burzyn D, Rassa JC, Kim D, Nepomnaschy I, Ross SR, Piazzon I. Toll-like receptor 4-dependent activation of dendritic cells by a retrovirus. J Virol. 2004;78:576-84.

58. Falvo JV, Tsytsykova AV, Goldfeld AE. Transcriptional control of the TNF gene. Curr Dir Autoimmun. 2010;11:27-60.

59. Novotny V, Prieschl EE, Csonga R, Fabjani G, Baumruker T. Nrf1 in a complex with fosB, c-jun, junD and ATF2 forms the AP1 component at the TNFa promoter in stimulated mast cells. Nucleic Acids Res. 1998;26:5480-5.

60. Van Der Bruggen T, Nijenhuis S, Van E, Verhoef J, Van Asbeck BS. Lipopolysaccharide-induced tumor necrosis factor alpha production by human monocytes involves the raf-1/MEK1-MEK2/ERK1/ERK2 pathway. Infect Immun. 1999;67:3824-9.

61. Tsai EY, Falvo JV, Tsytsykova AV, Barczak AK, Reimold AM, Glimcher LH, et al. A lipopolysaccharide-specific enhancer complex involving Ets, Elk-1, Sp1, and CREB binding protein and p300 is recruited to the tumor necrosis factor alpha promoter in vivo. Mol Cell Biol. 2000;20:6084-94.

62. Buss H, Dörrie A, Schmitz ML, Hoffmann E, Resch K, Kracht M. Constitutive and interleukin-1-inducible phosphorylation of p65 NF-kB at serine 536 is mediated by multiple protein kinases including IKB kinase (IKK)-a, IKK 3 , IKKE, TRAF family member-associated (TANK)-binding kinase 1 (TBK1), and an unknown kinase and couples p65 to TATA-binding protein-associated factor II31-mediated interleukin-8 transcription. J Biol Chem. 2004;279:55633-43.

63. Khoshnan A, Ko J, Watkin EE, Paige LA, Reinhart PH, Patterson PH. Activation of the IKB kinase complex and nuclear factor-kB contributes to mutant huntingtin neurotoxicity. J Neurosci. 2004;24:7999-8008.

64. Träger U, Andre R, Lahiri N, Magnusson-Lind A, Weiss A, Grueninger S, et al. HTT-lowering reverses Huntington's disease immune dysfunction caused by NFkB pathway dysregulation. Brain. 2014;137:819-33.

65. García Lopez MA, Aguado Martínez A, Lamaze C, Martínez-A C, Fischer T. Inhibition of dynamin prevents CCL2-mediated endocytosis of CCR2 and activation of ERK1/2. Cell Signal. 2009;21:1748-57.

66. Kalesnikoff J, Uber M, Lam V, Damen JE, Zhang J, Siraganian RP, et al. Monomeric lgE stimulates signaling pathways in mast cells that lead to cytokine production and cell survival. Immunity. 2001;14:801-11. 
67. Apostol BL, Illes K, Pallos J, Bodai L, Wu J, Strand A, et al. Mutant huntingtin alters MAPK signaling pathways in PC12 and striatal cells: ERK1/2 protects against mutant huntingtin-associated toxicity. Hum Mol Genet. 2006;15:273-85.

68. Bowles KR, Jones L. Kinase Signalling in Huntington's disease. J Huntingtons Dis. 2014;3:89-123.

69. Husebye H, Aune MH, Stenvik J, Samstad E, Skjeldal F, Halaas $\varnothing$, et al. The Rab11a GTPase controls toll-like receptor 4-induced activation of interferon regulatory factor-3 on phagosomes. Immunity. 2010;33:583-96.

70. Okumura S, Kashiwakura Jl, Tomita H, Matsumoto K, Nakajima T, Saito H, et al. Identification of specific gene expression profiles in human mast cells mediated by toll-like receptor 4 and FceRl. Blood. 2003;102:2547-54.

71. Meng Z, Yan C, Deng Q, Dong X, Duan ZM, Gao DF, et al. Oxidized lowdensity lipoprotein induces inflammatory responses in cultured human mast cells via toll-like receptor 4. Cell Physiol Biochem. 2013;31:842-53.

72. Keck S, Müller I, Fejer G, Savic I, Tchaptchet S, Nielsen PJ, et al. Absence of TRIF signaling in lipopolysaccharide-stimulated murine mast cells. J Immunol. 2011;186:5478-88.

73. Uronen-Hansson H, Allen J, Osman M, Squires G, Klein N, Callard RE. Toll-like receptor 2 (TLR2) and TLR4 are present inside human dendritic cells, associated with microtubules and the Golgi apparatus but are not detectable on the cell surface: integrity of microtubules is required for interleukin-12 production in response to internalized bacteria. Immunology. 2004;111:173-8.

74. Zanoni I, Ostuni R, Marek LR, Barresi S, Barbalat R, Barton GM, et al. CD14 controls the LPS-induced endocytosis of toll-like receptor 4. Cell. 2011:147:868-80.

75. Shibata T, Motoi Y, Tanimura N, Yamakawa N, Akashi-takamura S, Miyake K. Intracellular TLR4/MD-2 in macrophages senses gram-negative bacteria and induces a unique set of LPS-dependent genes. Int Immunol. 2011;23:503-10.

76. Malaviya R, Ikeda T, Ross E, Abraham SN. Mast cell modulation of neutrophil influx and bacterial clearance at sites of infection through TNF-a. Nature. 1996;381:77-80.

77. Supajatura V, Ushio H, Nakao A, Akira S, Okumura K, Ra C, Ogawa H.

Differential responses of mast cell Toll-like receptors 2 and 4 in allergy and innate immunity. J Clin Invest. 2002;109:1351-9.

78. Dong H, Wang Y, Zhang X, Zhang X, Qian Y, Ding H, et al. Stabilization of brain mast cells alleviates LPS-induced neuroinflammation by inhibiting microglia activation. Front Cell Neurosci. 2019;13:1-15.

\section{Publisher's Note}

Springer Nature remains neutral with regard to jurisdictional claims in published maps and institutional affiliations.

Ready to submit your research? Choose BMC and benefit from:

- fast, convenient online submission

- thorough peer review by experienced researchers in your field

- rapid publication on acceptance

- support for research data, including large and complex data types

- gold Open Access which fosters wider collaboration and increased citations

- maximum visibility for your research: over $100 \mathrm{M}$ website views per year

At $\mathrm{BMC}$, research is always in progress.

Learn more biomedcentral.com/submissions 